University of Nebraska - Lincoln

DigitalCommons@University of Nebraska - Lincoln

$11-18-2020$

Flowers are essential to maintain high beetle diversity (Coleoptera) in a Neotropical rainforest canopy

Susan Kirmse

Caroline S. Chaboo

Follow this and additional works at: https://digitalcommons.unl.edu/unsmaffil

Part of the Biodiversity Commons, Ecology and Evolutionary Biology Commons, Natural Resources and Conservation Commons, Other Environmental Sciences Commons, and the Research Methods in Life Sciences Commons

This Article is brought to you for free and open access by the Museum, University of Nebraska State at DigitalCommons@University of Nebraska - Lincoln. It has been accepted for inclusion in Publications of UNSM Staff and Affiliates by an authorized administrator of DigitalCommons@University of Nebraska - Lincoln. 


\title{
Flowers are essential to maintain high beetle diversity (Coleoptera) in a Neotropical rainforest canopy
}

\section{Susan Kirmse ${ }^{1}$ and Caroline S Chaboo ${ }^{2}$}

1 Florida State Collection of Arthropods, Museum of Entomology, Gainesville, FL, USA

2 Systematics Research Collections, University of Nebraska State Museum,

Lincoln, NE, USA

Corresponding author — Susan Kirmse susankirmse@gmx.net

ORCID

Susan Kirmse http://orcid.org/0000-0003-4636-7492

Caroline S Chaboo http://orcid.org/0000-0002-6983-8042

\begin{abstract}
Many hypotheses have been proposed to explain the megadiversity of angiosperms and insects. Flowers and their pollinators represent the most common terrestrial mutualistic interaction today and this is thought to have driven the evolution of angiosperms and their visitors. Within the framework of that interaction, this paper develops and tests two new hypotheses: 1) megadiversity of canopy beetles in tropical rainforests is largely based on flower resources, and 2) the majority of adult canopy beetles are adapted to visit flowers. To test hypothesis 1, the beetle fauna associated with 23 canopy tree species (13 families, 45 individuals) in a 1.4 ha canopy plot of pristine lowland tropical rainforest in southern Venezuela was
\end{abstract}

Published as: Susan Kirmse \& Caroline S Chaboo (2020) Flowers are essential to maintain high beetle diversity (Coleoptera) in a Neotropical rainforest canopy, Journal of Natural History, $54: 25-26,1661-1696$.

DOI: 10.1080/00222933.2020.1811414

Copyright (c) 2020 Informa UK Limited, Taylor \& Francis Group. Used by permission. Submitted 2 February 2020; accepted 13 August 2020; published 18 November 2020. 
studied over one year. In total, 6698 adult beetles were collected and identified to 859 species in 44 families. Of these 859 species, 647 species (75.3\%) were found with at least one individual on flowering trees, and 527 species (61.4\%) were associated exclusively with flowering trees. The proportion of beetle species visiting exclusively small white flowers of the morphological generalist syndrome amounts to $36.6 \%$ of the entire canopy beetle community. Based on these findings, the second hypothesis was formulated that canopy beetles are specially adapted flower visitors. To test hypothesis 2, a sub-set study was conducted of the beetles visiting flowers of one tree species in the canopy plot, Hymenopus heteromorphus (Benth.) Sothers and Prance (Chrysobalanaceae). This is a mass-flowering tree with white flowers of a generalized morphology. A total of 440 adult beetles were collected in 20 days and identified to 138 species in 54 genera in 23 families. This assemblage was restricted to the flowering season of this tree. Data collected for $\mathrm{H}$. heteromorphus and other mass-flowering tree species in the same plot indicates that a particular combination of flowering characteristics - massively flowering, white color, and generalized morphology - attracts the highest diversity of beetles. These findings together suggest that the enormous diversity of canopy beetles in Amazonian tropical rainforests is due mainly to flowers and that mass-flowering trees with small white flowers of the generalist syndrome play a particularly crucial role in assembly and nourishment of this megadiverse beetle community.

Keywords: Canopy crane, Amazonia, mass-flowering, generalist flower syndrome, pollinators, flower visitors, florivory

\section{Introduction}

Tropical rainforests are the most speciose terrestrial ecosystems and harbor the most insect species (Myers et al. 2000; Miller et al. 2002; Hamilton et al. 2010; Stork 2017). They exhibit the greatest diversity of pollination systems and the highest prevalence of insect pollination (Bawa 1990; Ollerton et al. 2006, 2011; Ollerton 2017). It is accepted generally that most tropical trees are pollinated by insects (Bawa and Beach 1981; Kevan and Baker 1983; Bawa 1990). Consequently, angiosperms and their animal pollinators represent the most frequent mutualistic interaction in terrestrial ecosystems (Kearns and Inouye 1997; Ollerton et al. 2011) with about 350,000 animal species pollinating the approximately 352,000 species of flowering plants (Paton et al. 2008). On the other hand, over 300,000 animal species directly depend on floral resources (Buchmann and Nabhan 1996). About 30\% of arthropod species may utilize flowers regularly to feed (nectar, pollen, floral parts) or acquire other resources such as oviposition sites (Wardhaugh 2015). Despite this remarkable association, Wardhaugh 
(2015) noted that studies recording all visitors to flowers are rare. This particularly applies to the megadiverse Neotropical rainforests which we now understand to have both the greatest diversity of trees (Gentry 1982; Daly and Mitchell 2000) and the greatest diversity of canopy-inhabiting insects, including beetles (Erwin 1983; Adis et al. 1984; Basset et al. 2003b).

Flowers are a very important resource for insects, including beetles, providing food, scents, shelter, sites for meeting partners, mating, and for juvenile development (Gottsberger 1989; Irvine and Armstrong 1990; Young 1990; Gottsberger and Silberbauer- Gottsberger 1991; Listabarth 1992; Nicolson 2007). For example, a leaf beetle that pollinates an Araceae species used the spathe chamber as a mating site (Kato 1996). Hopliines (Scarabaeidae) pollinate flowers of African Iridaceae and use them as sites for assembly, competitive behavior and copulation (Goldblatt and Manning 2006). In addition, adults in certain beetle families use flowers to deposit eggs; for example, eggs of Anthonomini weevils and Nitidulidae develop in flower buds (Burke 1976; Crowson 1981). Thus, the availability of food sources for adults shapes their choice of oviposition sites (Cook et al. 2004); consequently, feeding on plant structural tissue in larvae and on plant-provided food supplements in adult beetles is often closely interlinked.

Beetles comprise 400,000 species and form the most species-rich order on Earth (Ślipiński et al. 2011). Armstrong (1979) estimated that $25 \%$ of Australian beetle families are anthophilous. Within megadiverse tropical forests, beetles comprise an important proportion of the flower-visiting fauna (Goulson 1999). Kato et al. (2008) examined 145 plant species in a tropical monsoon forest, Laos, and found Coleoptera was the second most abundant flower-visitor group (at 16\% of all visitors). In a lowland dipterocarp forest in Malaysia, Sakai et al. (1999) found beetles accounted for $74 \%$ of flower visitors during the flowering period of a single emergent tree, Shorea parvifolia Dyer (Dipterocarpaceae). In an Australian tropical rainforest, a detailed analysis of the beetle fauna revealed that flowers were utilized by approximately $41 \%$ of the species (Wardhaugh et al. 2012). Wardhaugh (2015) estimated that $20 \%$ of Coleoptera species found in a large study were visiting flowers; thus, he estimated that there are about 80,000 described flower visitors and so flowers potentially could support more beetle species than in any other insect order. 
Despite Wardhaugh's (2015) remarkable estimation, very few studies have documented the general visitation of beetles to flowers in megadiverse tropical rainforests, or analyzed beetle utilization of specific floral resources, their impacts on the plants, roles they play in pollination, and their adaptations to feed on flower resources. This paper addresses some of these significant gaps about beetle-plant associations. We outline some of these gaps below.

Beetles are not only abundant flower visitors, but they also play an important role in pollination. Overall, Coleoptera are considered fourth in terms of pollinator importance (Ollerton 2017), but they are often the second most important visitor group in tropical ecosystems (Corlett 2004; Wardhaugh 2015; Ollerton 2017; Sayers et al. 2019). Beetle pollinators were determined to be more important in tropical forests compared to temperate forests (Gottsberger 1974). Irvine and Armstrong (1990) estimated that $17 \%$ of plants in Australia are pollinated by beetles. In an Australian dry rainforest, 22\% of plants were found to be beetle-pollinated (Hansman 2001). Momose et al. (1998) similarly found that $20 \%$ of 270 plant species in an Asian dipterocarp forest are beetle-pollinated, representing the second most abundant pollination system in that forest. Corlett (2004) reviewed beetles as the second important pollinator group in Indo-Malayan lowland forests. In Costa Rica, $40.8 \%$ of cloud forest herbs were found to be pollinated by beetles (Ramirez and Seres 1994). In another rainforest of Costa Rica, Kress and Beach (1994) found $12.7 \%$ of the 276 studied flowering plant species to be beetle-pollinated. Despite all these findings, we still know little about beetle visitation to flowers in tropical forest canopies, and even less about the diversity of that relationship because this association is documented so poorly (Vizentin-Bugoni et al. 2018).

Flower-visiting beetles can be both herbivores and pollinators or just predators awaiting prey. Florivory - damage to bracts, sepals, petals, stamens and pistils, pollen and ovules (Burgess 1991) - is a primary plant-animal interaction, whereas pollination is one possible secondary outcome of flower visitation (Frame 2003). Florivory is common and may even surpass leaf herbivory in magnitude and impact (McCall and Irwin 2006). Many adult beetles feed primarily or exclusively on plant-provided food supplements such as nectar and pollen (Wackers et al. 2007; Kirmse and Chaboo 2018). Although nectar is 
the most important reward in animal-pollinated plants (Simpson and Neff 1983; Proctor et al. 1996), Dafni et al. (1990) determined that nectar-feeding was a more recent development in geological time and pollen is generally more important in beetle-flower associations. There are many obligate flower-visiting beetles exhibiting highly specialized adaptations to locate and handle flowers efficiently (Wardhaugh et al. 2013). Pollen-collecting mouthparts of beetles often possess combs of setae on the mandibles, palps or on other mouthparts such as in Oedemeridae and Mordellidae (Barth 1985; Krenn et al. 2005) (Figure 1). Specialized nectar-feeding Coleoptera have prognathous mouthparts that are acuminate with maxillary palps, galaea and laciniae (Fuchs 1974) (Figure 1). The prolonged mouthparts and the acumination of the frontoclypeus are extremely developed in nectar-feeding Buprestidae (Bellamy 1986; Gardner 1989) and Cerambycidae (McKeown 1947; Scambler 1993). The prolongation of mouthparts is also characteristic in flower-visiting Alleculinae, Cantharidae, Lycidae, Meloidae, Mordellidae, Oedemeridae, Rhipiphoridae and some Scarabaeidae (Crowson 1981; Krenn et al. 2005; Nicolson 2007). Mouthparts of some specialized flower-visiting Cetoniinae (Scarabaeidae) lack cutting edges but bear numerous setae and dense brushes on the maxillae to feed on nectar and pollen (Johnson and Nicolson 2001). However, most flowervisiting beetle species lack suctorial mouthparts to feed on nectar (Jervis 1998; Nicolson 2007).

Florivory arose early in the history of beetles. Basal lineages of modern insect pollinators could have originated during the Jurassic, probably as generalists on seed plants (Labandeira 1998). Beetles are among the earliest pollinators or even the oldest ones (Grimaldi 1999; Cai et al. 2018; McKenna et al. 2019). Specialized beetle-pollinated flowers were apparent by the Cretaceous (Bernhardt 2000; Bao et al. 2019). For example, beetle pollination of members of the Nymphaeaceae represents an ancient mutualistic partnership that originated in the mid-Cretaceous (Gandolfo et al. 2004). Still, only a few plant families are pollinated exclusively by beetles in contrast to the generalist flower syndrome (Gottsberger 1989, 1990); however, in 34 families of flowering plants at least one species was found to be pollinated primarily by beetles (Bernhardt 2000). Beetle-pollinated systems are conservative and have often only few visitors (Bernhardt 2000). Bernhardt (2000) proposed that plants pollinated exclusively by 

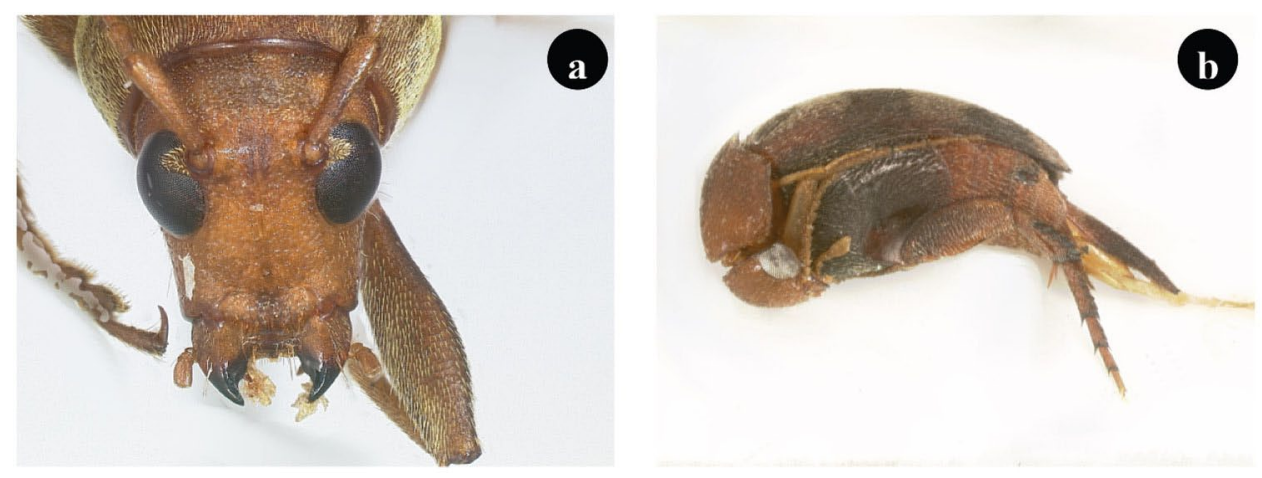

Figure 1. Specialized flower-visiting beetles often have mouth parts adapted to feed effectively on pollen and nectar. Adaptations can include prolonged mouthparts and dense brushes on the maxillae as in (a) Mecometopus Thomson sp. (Cerambycidae), or enlarged and securiform maxillary palpomeres as in (b) Mordellistena Costa sp. 3 (Mordellidae).

beetles exhibit four overlapping modes of floral presentation: bilabiate, brush, chamber and painted bowl blossoms. Specialized beetlepollinated systems are particularly diverse in the wet tropics to warm temperate-Mediterranean zones. The majority of magnoliids (basal dicotyledons) and basal monocotyledons are specialized in beetle pollination (Bernhardt 2000). Most species of Annonaceae are pollinated by beetles (Gottsberger 2012). For example, Annona L. (Annonaceae) flowers exhibit nocturnal heating and strong odor which is adapted to dynastid beetle pollination by Cyclocephala Dejean yet there is little specificity in this interaction (Gottsberger 1999). A highly specialized cantharophilous syndrome is also known from some Arecaceae (Listabarth 1994) and Araceae (Garcia-Robledo et al. 2004), however, little specificity between beetle and plant flower has been found even in these specialist flowers.

Here we focus on floral resource use of canopy beetles and analyze the strength and specificity of the relationship between flowers and beetles to address the gaps about beetle-plant associations. This documentation is also necessary to understand beetle megadiversity in rainforests. Author SK constructed a Ph.D. study to inventory the canopy beetle community in an Amazonian rainforest, Venezuela. Her highly-detailed data reveal novel insights into patterns of these rich beetle-tree associations (Arndt et al. 2001; Kirmse et al. 2003; Kirmse and Chaboo 2018, 2019; Kirmse and Ratcliffe 2019; Kirmse and Johnson 2020). 
In this paper, we develop and test two new hypotheses:

Hypothesis 1. Megadiversity of canopy beetles in tropical rainforests is largely based on flower resources. To test this, we conduct an inventory of canopy beetles and their food resources. Our hypothesis 1 is supported if the majority (>50\%) of beetle species are found to be associated with flowers.

Hypothesis 2. The majority of adult canopy beetles are adapted flower visitors. To test this, we must determine first if adult beetles subsist on flower resources. Within the survey, a finding that at least $50 \%$ of the beetle species only use flowers would support our hypothesis 2 . We must also determine the specificity of the flower-visiting beetles. So we conduct a subset analysis of the beetles associated with one mass-flowering canopy tree species and compare this flower-visiting assemblage with two other nonflowering tree species of Chrysobalanaceae (Kirmse and Chaboo 2019).

While conducting the inventory and addressing these two hypotheses, our findings allow comparison of the beetle fauna of the massflowering Chrysobalanaceae with a previous study, Kirmse et al. (2003), of two other mass-flowering trees species with the same flower syndrome to identify general patterns.

\section{Material and methods}

\section{Project context}

The canopy beetle research of author SK was conducted as part of the Surumoni Crane Project (1995-2000), a cooperation between the Austrian Academy of Science and the Venezuelan government (Morawetz 1998) under permit no. 15-1277 from Servicio Autonoma de Fauna, Ministerio del Ambiente y de los Recursos Naturales Renovables, Venezuela. A tower crane was installed in a remote part of lowland moist forest in the northern Amazonian basin. The canopy crane system was $42 \mathrm{~m}$ in height and ran on $120 \mathrm{~m}$ long rails. An area of about 1.4 ha 
was accessible with the crane's $40 \mathrm{~m}$ long swing. A gondola carrying the scientists and their equipment enabled movement between the tree crowns (at $35 \mathrm{~m}$ maximum).

The general canopy beetle survey was conducted between 1997 and 1999 and covers a full year. Observations and collections of beetles were carried out during the following periods: September to November 1997; May to August and December 1998; January to April 1999. Additional aerial trap collection in October-November 1999 targeted a single tree species, Matayba guianensis Aubl. (Sapindaceae), to compare the beetle assemblages of two main flowering seasons.

Multiple studies have been published already from the Surumoni Crane Project: project overview (Winkler and Listabarth 2003); canopy structure (Anhuf and Rollenbeck 2001); plant diversity (Morawetz et al. 1998; Listabarth 1999; Komposch and Hafellner 2000; Nieder et al. 2000; Wesenberg 2004); and canopy beetles (Arndt et al. 2001; Kirmse et al. 2003; Kirmse and Chaboo 2018, 2019; Kirmse and Ratcliffe 2019; Kirmse and Johnson 2020).

\section{Study site}

The study site is located in the upper Orinoco region in southern Venezuela (state of Amazonas) ( $3^{\circ} 10^{\prime} \mathrm{N}, 65^{\circ} 40^{\prime} \mathrm{W} ; 105 \mathrm{~m}$ asl). The crane was installed at the small black-water river Surumoni, a tributary of the large white-water river Orinoco. The Surumoni area belongs to the Japura/Negro moist forests ecoregion (Dinerstein et al. 1995) or Imeri province (Morrone 2014) that extends from Brazil to southern Venezuela, Colombia and Peru.

The study area received a gross rainfall of about $3100 \mathrm{~mm}$ with a strong peak in the annual precipitation from May to July, then a lower peak in September and October (Anhuf et al. 1999). There is no distinct dry season in the area as precipitation was never fewer than 100 $\mathrm{mm}$ per month. Year to year fluctuations of about $500 \mathrm{~mm}$ occurred. The average annual temperature in the study area is ca. $26^{\circ} \mathrm{C}$. Slight variations between the coolest month $\left(25^{\circ} \mathrm{C}\right)$ and the warmest month $\left(26.5^{\circ} \mathrm{C}\right)$ and a daily range of $5-10^{\circ} \mathrm{C}$ are characteristic. 


\section{Vegetation}

The vegetation of the study area has been described in Winkler and Listabarth (2003) and we have added details about the vegetation structure (Kirmse and Chaboo 2018). To summarize, this forest is classified as terra firme moist lowland tropical rainforest (Prance 1979). The upper canopy in the area ranges usually from 25 to $27 \mathrm{~m}$ in height. Only a few emergent trees rise to a height of $35 \mathrm{~m}$. The forest in the study area is frequently interrupted by light gaps, thus the canopy was not completely closed.

Altogether, 316 species of higher plants were identified in the crane plot. These belong to 202 genera from 76 families (Winkler and Listabarth 2003). The species-richest plant families were Fabaceae (23), Orchidaceae (19 species), Araceae (16 species), Rubiaceae (15 species), Lauraceae (13 species), Chrysobalanaceae (10 species) and Annonaceae (10 species). Epiphytes and hemiepiphytes comprised 53 species (Engwald et al. 2000).

There were more than 800 individual trees $\geq 10 \mathrm{~cm} \mathrm{DBH}$ (diameter at breast height) belonging to 141 tree species within the crane plot. All these trees were tagged (e.g. ID tag \#970) and identified by botanists from the Universities of Vienna, Austria and Leipzig, Germany. Anhuf and Rollenbeck (2001) provide the crown area map including the tagged trees. Frequent species in the tree fraction with a DBH of $\geq 10 \mathrm{~cm}$ were Dialium guianense (Aubl.) Sandwith (Fabaceae), Goupia glabra Aubl. (Goupiaceae), Ocotea aff. amazonica (Meisn.) Mez (Lauraceae), Oenocarpus bacaba Mart. (Arecaceae) and Ruizterania trichanthera (Spruce ex Warm.) Marc.-Berti (Vochysiaceae) (Wesenberg 2004).

\section{Beetle sampling}

To test our hypotheses 1 and 2 about canopy beetles and flower resources and beetle adaptations to flowers, we conducted an inventory with close observations of the beetle fauna of canopy trees during flowering and non-flowering seasons. The coverage area within the canopy plot for the inventory of this canopy beetle assemblage includes 23 canopy tree species (23 genera, 13 plant families). Other plants in the canopy - epiphytes and lianas - were excluded for this current beetle study. Trees were chosen with consideration of their 
taxonomic representativeness, widespread or regionally distributed and speciose rich/poor genera and families. Another criterion was their abundance in the crane plot (i.e. dominant, common, singletons). Furthermore, trees selected for our canopy beetle survey, were either completely free from epiphytes and lianas or bore only small ones to minimize errors of beetle-host associations. Using the crane's gondola from one position, all trees were freely accessible for investigation, collecting and observations. Using the tower crane (see Kirmse and Ratcliffe 2019: Figure 1), the crowns of tree species in the upper (approximately 25-30 m height) and middle canopy (approximately 18-25 $\mathrm{m}$ height) were searched regularly by hand for Coleoptera during day and night. Depending on the number of crown-associated beetles, the observation time per tree crown was 30 mins from one gondola position. Observed beetles were captured by net, hand or through branch and foliage beating. These collection methods were not structured to provide quantitative data.

To obtain semi-quantitative sampling results, standard-sized aerial traps were used to collect flying beetles (Basset et al. 1997; see Kirmse and Chaboo 2018: Figure 1(d)). Altogether 10 traps were installed within different tree crowns at the same time. These window traps consisted of two panels of transparent plexiglass fixed over cross (length of $30 \mathrm{~cm} \times$ height of $25 \mathrm{~cm}$ ). Beneath the plexiglass panels was a plastic tube ending in a container, filled with water mixed with a surface tension-diminishing detergent, for collecting the beetles. The containers with trapped beetles were cleaned out as far as possible every other day.

\section{Processing of beetles}

The collected beetles were kept in $70 \%$ ethanol, and a portion was pinned later. The beetles were assigned to morphospecies by author SK. Some species were identified later by specialists: Buprestidae by Charles L. Bellamy, Cantharidae and Lycidae by Alistair S. Ramsdale, Cerambycidae by Ubirajara R. Martins, Chrysomelidae by Lourdes Chamorro, Shawn M. Clark, Wills Flowers, David Furth, Lev N. Medvedev and Davide Sassi, Cleridae by Weston Opitz, Curculionidae by Sergio Antonio Vanin, Elateridae by Paul J. Johnson and Claus Wurst, Lampyridae by Vadim R. Viviani, Mordellidae by John A. Jackman, 
Scarabaeidae by Brett C. Ratcliffe and Tenebrionidae by Martin Lillig. The family group names follow Bouchard et al. (2011). Voucher specimens of collected beetles are deposited in the Museo del Instituto de Zoologia Agricola 'Francisco Fernandez Yepez', Maracay, Venezuela, and in the Botanical Institute, Leipzig University, Germany.

\section{Ecological characterization of beetles}

The beetle species were ecologically characterized according to data and observations gained in the canopy. Species were assigned according to their observed diel activity either as nocturnal or diurnal species. Species which could not be clearly assigned either to diurnal or nocturnal activity (e.g. single individuals were found active during night and day, respectively) and species with unknown activity phases (only caught with the traps) were classified as 'indifferent'.

Host plants include all canopy trees in our plot where beetles were sampled. Beetle species with all specimens (regardless the number of individuals) recorded on only one host tree were classed as 'exclusive species'. 'Abundant species' were determined by their proportion of all beetles sampled on one distinct canopy host; these species were sampled with the most individuals. In the analyses of our $\mathrm{H}$. heteromorphus, the threshold was three trapped individuals or eight individuals hand-collected. The plant parts consumed by the beetles were categorized as leaves, extrafloral nectar (EFN), flowers and fruits.

For our general evaluation of the resource use of the entire beetle assemblage collected on the 23 canopy tree species we assigned all species collected on flowering trees as flower visitors. This evaluation of resource use is assigned to test hypothesis 1, how many adult beetles subsist on flowers. Thus, flower visitors include all beetle species collected on flowering trees, if no other diet was observed. We admit that this is a simplification to compare the association of all canopy beetle species of the entire canopy assemblage with resource availability (different parts of the tree canopies: i.e. leaves, fruits, flowers, extrafloral nectaries), as feeding observations are not available for each specimen and species, respectively. This applies particularly to beetle species which were caught exclusively in the traps. In exclusive flower visitors, all beetle individuals were collected on flowers and flowering trees, respectively. 

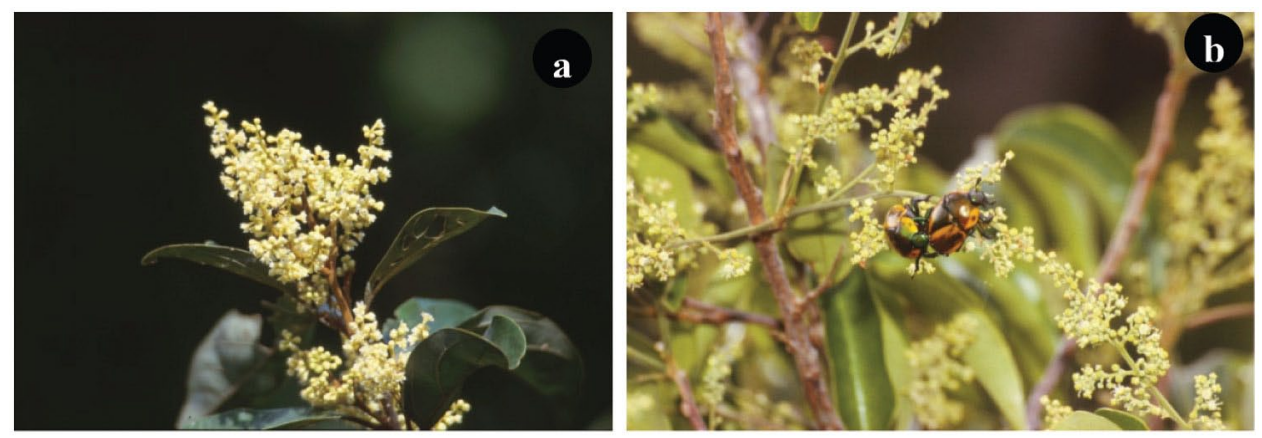

Figure 2. Small white flowers of the generalist pollination syndrome in a lowland rainforest canopy, Venezuela. (a) Flowers of Hymenopus heteromorphus (Benth.) Sothers and Prance var. heteromorphus (Chrysobalanaceae), March 1999. (b) Macraspis festiva Burmeister (Scarabaeidae) mating on flowering Matayba guianensis Aubl. (Sapindaceae), September 1997.

\section{Investigated flowering trees}

In total, 20 of 23 investigated canopy trees within the crane plot flowered at least once during the survey period. The flowers were distinguished according to their flower syndrome to clarify possible specific associations of the beetles with floral traits:

Generalist flower syndrome (Figure 2): These flowers have an open morphology that allows entry to a comparatively wide range of insect visitors (Howe and Westley 1986; Frame 2003). They are either flat or cup-shaped and of radial symmetry.

Other flower syndromes (see Kirmse and Chaboo 2019: Figure 1(a)): These have morphologies such as zygomorphic symmetry or tubular corollas representing more specialized pollination syndromes according to Faegri and Van der Pijl (1979), thus, they are historically considered to be adapted to the visitation of distinct pollinator taxa.

In our plot, the canopy trees with generalist white flowers include Euterpe precatoria Mart. and O. bacaba (Arecaceae); H. heteromorphus (Chrysobalanaceae) (Figure 2(a)); Tachigali guianensis (Benth.) Zarucchi and Herend. (Fabaceae); O. aff. amazonica (Lauraceae); Emmotum acuminatum (Benth.) Miers (Metteniusaceae); M. guianensis (Sapindaceae) (Figure 2(b)). Of these trees, H. heteromorphus, M. guianensis and T. guianensis were mass-flowering, i.e. producing a very high amount of flowers over a short period (Heinrich and Raven 1972; Frankie 1975). 
The canopy trees with flowers of other syndromes comprise: Guatteria schomburgkiana Mart. and Xylopia amazonica R.E. Fr. (Annonaceae); Couma utilis (Mart.) Mull. Arg. (Apocynaceae); Albizia pedicellaris (DC.) L. Rico, D. guianense and Senna cf. silvestris (Vell.) H. S. Irwin and Barneby (Fabaceae); G. glabra (Goupiaceae); Rhodostemonodaphne grandis (Mez) Rohwer (Lauraceae); Podocalyx loranthoides Klotzsch (Picrodendraceae); Ferdinandusa cf. elliptica (Pohl) Pohl (Rubiaceae); Qualea paraensis Ducke, R. trichanthera and Vochysia vismuifolia Spruce ex Warm. (Vochysiaceae).

\section{Target tree Hymenopus heteromorphus Benth. Sothers and Prance (Chrysobalanaceae)}

This paper targets beetle visitors to flowers of Hymenopus heteromorphus (Benth.) Sothers and Prance (Chrysobalanaceae). This tree species was chosen to compare its flower-visiting beetles to our previous study, Kirmse and Chaboo (2019), of two other Chrysobalanaceae tree species in the plot, Licania hebantha Mart. ex Hook. f. and Moquilea subarachnophylla (Cuatrec.) Sothers and Prance, that attracted extrafloral nectary- visiting beetles. To test hypothesis 2, we compared the beetle assemblages associated with different food resources of these confamilial tree species.

Hymenopus (Benth.) Sothers and Prance is a Neotropical genus with 28 species which are distributed from Central America (Costa Rica and Panama), Trinidad and Tobago to northern South America (Colombia, Venezuela, the Guianas, Ecuador, Bolivia, Peru and in Brazil mainly the Amazonian region) (Sothers et al. 2016). Hymenopus heteromorphus is morphologically variable and widespread and occurs in five varieties through Central and South America (Sothers et al. 2016). Our single investigated tree, \#970, belongs to the variety heteromorphus which grows in Trinidad, from Colombia, Venezuela and the Guianas through Brazil southwards to Peru and Bolivia (Sothers et al. 2016). This specific variety is commonest in periodically flooded forest, but it occurs elsewhere (Sothers et al. 2016). The whitish/yellowish flowers are tiny, $\sim 2 \mathrm{~mm}$ wide and length is $\sim 3 \mathrm{~mm}$, with a flat cup-like shape (Figure $2(a))$. The flowers are arranged in racemose panicles. Flowers have a weak sweet odor. The hermaphrodite flowers are actinomorphic to zygomorphic. A disc is present (Prance and Sothers 2009). 
Nine tree specimens of $H$. heteromorphus with a DBH of $\geq 10 \mathrm{~cm}$ grew inside the crane plot. One specimen of $H$. heteromorphus (ID tag \#970; Figure 2(a)) and its flower visitors were monitored during one flowering season, 25 February to 16 March 1999 (20 days). The beetles were hand-collected throughout the flowering season during the day and the night. In addition, one window trap was placed within the tree crown to provide semiquantitative data. This tree \#970 had a height of $22 \mathrm{~m}$ and belonged to the middle to lower upper canopy; its crown diameter was about $4 \mathrm{~m}$. Flower buds were found on this tree at the end of February. The first flowers were open on 3 March. On 5 March, the tree was full in bloom; by 9 March, the zenith of open flowers was already passed. From 12 March onwards, only a few open flowers were remaining on this tree specimen. According to Wesenberg (2004), this tree flowered usually once a year between the end of January and start of April. We estimated the amount of flowers on this single tree \#970 was approximately 100,000 in the flowering season of 1999 . For this evaluation, the number of flowers was counted on an average twig and then calculated for branches and the entire crown.

\section{Data analyses}

We based our general evaluation of the flower-visiting beetle assemblage on all beetles sampled on a total of 23 tree species and 45 tree specimens (Table 4). Canopy trees chosen are being described separately (Kirmse in prep.). The assemblage during a flowering period was separated by assemblages collected during other phenological seasons. The flower visitors comprise all beetles observed and sampled during a flowering season of a particular tree. From this assemblage, we subtracted all beetle species which were either assigned to other diets (e.g. leaf feeders) or which were residents on a particular tree and were not observed visiting flowers. Beetles were assigned to a specific diet independent of their abundances including singletons. Detailed analyses of host specificity patterns will be addressed separately (Kirmse in prep.).

We compared the specificity and diversity of the trees presented in the results section as follows: Our three tree species of Chrysobalanaceae were compared on the basis of the total samples during a restricted phenological season (flushing and flowering, respectively). 
All three Chrysobalanaceae were sampled each with one trap and monitored for each 30 minutes from one gondola position making the sampling effort comparable. To compare our three analyzed massflowering tree species with small white generalist flowers, we used only the standardized trap sample for each one flowering season due to an unequal effort in the hand collections. General diversity patterns of the entire beetle assemblage and statistical quantifications will be the subject of more comprehensive analyses (Kirmse in prep.).

For our estimation of the number of flower-visiting beetle species in our canopy plot and on Amazonian tree species (see Ter Steege et al. 2016) we included only beetle species collected exclusively on flowering trees. The average number of exclusive flower visitors of our 20 tree species corresponds to the average generalization level $L$ (Olesen et al. 2007). In contrast, we included all flower-visiting beetle species to calculate the relative generalization level $L / A$ of our massflowering tree species.

\section{Statistical analyses}

The comparisons of the samples were done with EstimateS (Version 9.1.0; Colwell 2013). The Shannon diversity and the estimation of species richness was calculated with PAST (Version 3.21; Hammer et al. 2001).

For diversity measure we used the exponential of the Shannon index which takes into account the number of individuals and the number of taxa. High values indicate many taxa, each with few individuals. To compare the samples, we used the classic Jaccard index and the complement of the Bray-Curtis measure which takes the abundances into account.

The expected number of species was plotted against the number of individuals to estimate the potential species richness of the assemblages. Estimations of species richness were performed by rarefaction by means of the abundance-based richness estimator Chao 1 due to the high proportion of rare species. 


\section{Results}

Over the one year of study (1997-1999), we sampled 6698 adult beetles on 23 canopy tree species. These adults are identified to 859 beetle species in 44 families. Of this total assemblage, $61.4 \%$ of the species $(N=527)$ were exclusively on flowering trees, thus supporting our hypothesis 1 . Three considerations indicate the specificity of flower-visiting adult beetles (hypothesis 2): First, of these exclusive flower visitors, 314 beetle species (59.6\%) visited only small white flowers of the generalist syndrome. Second, we found the flower-visiting beetle assemblage of our target tree $H$. heteromorphus restricted to the flowering season. Third, the flower-visiting beetle assemblage is clearly distinct, as we found little overlap with the beetle communities visiting the two confamilial nonflowering tree species.

\section{Flower visitors of $\mathrm{H}$. heteromorphus in the canopy plot}

A single tree of $H$. heteromorphus was selected for intense study of its visitors during a 13- day flowering period, using one window-pane trap and diurnal and nocturnal inspection by author SK. This tree bore flower buds at the end of February 1999. Only five solitary beetles were recorded at the flower buds from 25 February to 1 March. The first buds opened from 3 March onwards, and flower-visiting beetles were observed regularly. Wilting of most flowers was dated on 14 March. On 16 March daytime, there were still some beetles visiting flowers, whereas from 12 March onwards, just single flower-visiting beetles were found at night. The trap collected 53 specimens from 5-7 March, 40 specimens from 8-9 March, 21 specimens from 10-12 March and 45 specimens from 13-15 March.

Altogether 440 adults were collected on the flowers of the single $H$. heteromorphus tree. These adults are identified to 138 beetle species in 23 families (Table 1). Eighty-seven species were represented by only a single specimen. Seventy-five of the total 138 species were captured only by hand. In contrast, 43 species were collected only with the trap. One hundred and thirty-eight beetle species were found visiting the flowers of $H$. heteromorphus and the majority was diurnal, occurring on this tree only during daytime. Over the 13-day flowering period, the trap collected 19 diurnal species and 15 nocturnal 
Table 1. Adult beetles (Coleoptera) documented during the flowering season of Hymenopus heteromorphus (Benth.) Sothers and Prance (Chrysobalanaceae) in a lowland rainforest canopy, Venezuela.

\begin{tabular}{|c|c|c|c|c|c|c|c|c|c|}
\hline \multirow[b]{2}{*}{ Family } & \multicolumn{2}{|c|}{ \# individuals } & \multicolumn{2}{|c|}{ \# spp. total } & \multirow[b]{2}{*}{$\begin{array}{c}\text { only hand } \\
\text { capture }\end{array}$} & \multicolumn{2}{|c|}{ \# spp. exclusive } & \multicolumn{2}{|c|}{ \# exclusive flower visitor } \\
\hline & total & trapped & total & $N \geq 2$ & & total & $N \geq 2$ & total & $\begin{array}{l}\text { small white } \\
\text { flowers }\end{array}$ \\
\hline Anthribidae & 4 & & 1 & 1 & 1 & 1 & 1 & 1 & 1 \\
\hline Brentidae & 3 & & 3 & & 3 & 1 & & 3 & 2 \\
\hline Buprestidae & 1 & & 1 & & 1 & & & 1 & \\
\hline Cantharidae & 15 & 6 & 7 & 2 & 3 & & & 3 & 2 \\
\hline Carabidae & 2 & 1 & 2 & & 1 & 1 & & 1 & 1 \\
\hline Cerambycidae & 21 & 3 & 10 & 4 & 8 & 2 & 1 & 9 & 9 \\
\hline Chrysomelidae & 109 & 20 & 36 & 13 & 22 & 9 & 2 & 25 & 18 \\
\hline Cleridae & 30 & 2 & 2 & 2 & 1 & & & 2 & \\
\hline Coccinellidae & 2 & 2 & 1 & 1 & & & & 1 & \\
\hline Cryptophagidae & 2 & 1 & 1 & 1 & & 1 & 1 & 1 & 1 \\
\hline Curculionidae & 138 & 64 & 32 & 13 & 13 & 3 & & 20 & 17 \\
\hline Dermestidae & 8 & 8 & 2 & 1 & & & & 2 & 1 \\
\hline Elateridae & 1 & 1 & 1 & & & & & 1 & \\
\hline Eucnemidae & 1 & & 1 & & 1 & 1 & & 1 & 1 \\
\hline Lampyridae & 1 & & 1 & & 1 & & & & \\
\hline Lycidae & 1 & & 1 & & 1 & 1 & & 1 & 1 \\
\hline Melyridae & 4 & 1 & 4 & & 3 & 2 & & 4 & 3 \\
\hline Mordellidae & 61 & 39 & 12 & 7 & 6 & 2 & 1 & 12 & 7 \\
\hline Scarabaeidae & 28 & 6 & 12 & 6 & 8 & 2 & 1 & 10 & 5 \\
\hline Scyrtidae & 4 & 4 & 4 & & & 2 & & 3 & 2 \\
\hline Scraptiidae & 1 & & 1 & & 1 & 1 & & 1 & 1 \\
\hline Staphylinidae & 1 & 1 & 1 & & & 1 & & 1 & 1 \\
\hline Tenebrionidae & 2 & & 2 & & 2 & 1 & & & \\
\hline Total & 440 & 159 & 138 & 51 & 75 & 31 & 7 & 103 & 73 \\
\hline
\end{tabular}

species comprising 52 diurnal and 23 nocturnal individuals. The other trapped flower visitors could not be clearly assigned either to diurnal or nocturnal species.

Most collected species are Chrysomelidae (trap $N=15 /$ total $N=$ 36) and Curculionidae (trap $N=19 /$ total $N=32$ ), followed by Mordellidae (trap $N=6 /$ total $N=12)$ and Scarabaeidae (trap $N=4 /$ total $N=$ 12). Excluding the singletons, these four beetle families were also the most species-rich. The window trap collected 159 individuals classified into 63 species and 15 families (Table 1) from 5-15 March 1999. Most individuals trapped belong to Curculionidae $(\mathrm{N}=64)$, Mordellidae $(\mathrm{N}=39)$ and Chrysomelidae $(\mathrm{N}=20)$. Identified species are listed in Tables 2 and $\mathbf{3}$ with some illustrated in Figure 1, Figure 2(b), and Figure 3. 
Table 2. Abundant species (trapped $N \geq 3$ or hand-collected $N \geq 8$ ) and number of individuals sampled during the flowering season of Hymenopus heteromorphus (Benth.) Sothers and Prance (Chrysobalanaceae) in a lowland rainforest canopy, Venezuela. $\mathrm{EFN}=$ extrafloral nectary.

\begin{tabular}{lllll} 
& & \multicolumn{2}{c}{$\#$ individuals } & \\
\cline { 3 - 4 } Family & Species & total & trapped & Diet \\
\hline Cantharidae & Chaulignathus Hentz sp. 6 & 5 & 3 & EFN \& flowers \\
Cerambycidae & Coremia plumipes (Pallas) & 8 & 0 & white flowers \\
Chrysomelidae & Colaspis Fabricius sp. & 9 & 0 & diverse plant parts \\
Chrysomelidae & Coroicona danieli Bechyne & 9 & 2 & exclusively \\
Chrysomelidae & Hecataeus Jacoby sp. & 20 & 0 & white flowers \\
Chrysomelidae & Zepherina cf. variegatus (Weise) & 13 & 2 & diverse flowers \\
Cleridae & Enoclerus Gahan sp. 1 & 27 & 0 & diverse flowers \\
Curculionidae & Baridinae sp. 61 & 4 & 4 & white flowers \\
Curculionidae & Baridinae sp. 1 & 24 & 5 & white flowers \\
Curculionidae & Conoderinae sp. 4 & 52 & 37 & white flowers \\
Curculionidae & Heilus Kuschel sp. 1 & 12 & 1 & diverse plant parts \\
Curculionidae & Pseudanthonomus Dietz sp. 2 & 3 & 3 & white flowers \\
Dermestidae & Cryptorhopalum Guerin-Meneville sp. 1 & 7 & 7 & white flowers \\
Mordellidae & Isotrilophus Liljeblad sp. & 31 & 26 & diverse flowers \\
Mordellidae & Mordellistena Costa sp. 2 & 8 & 5 & diverse flowers \\
Mordellidae & Mordellistena Costa sp. 3 & 5 & 5 & white flowers \\
Scarabaeidae & Isonychus Mannerheim sp. 2 & 5 & 3 & diverse flowers \\
\hline & & & & \\
\hline
\end{tabular}

Table 3. Identified species sampled during the flowering season of Hymenopus heteromorphus (Benth.) Sothers and Prance (Chrysobalanaceae) in a lowland rainforest canopy, Venezuela.

\begin{tabular}{llrr} 
Family & Species & \# spp. & \# individuals. \\
\hline Buprestidae Leach & Agrilaxia Kerremans & 1 & 1 \\
Cantharidae Imhoff & Chauliognathus Hentz & 3 & 11 \\
& Discodon Gorham & 3 & 3 \\
& Ditemnus LeConte & 1 & 1 \\
Carabidae Latreille & Agra Fabricius & 2 & 2 \\
Cerambycidae Latreille & Agaone notabilis (White) & & 2 \\
& Chrysoprasis aureicollis White & & 1 \\
& Coremia plumipes (Pallas) & 8 \\
& Eburodacrys sexmaculata (Olivier) & & 1 \\
& Mecometopus ion (Chevrolat) & 3 \\
& Mecometopus Thomson & 1 & 1 \\
& Megacyllene angulata (Fabricius) & & 1 \\
& Pirangoclytus flavius (Bates) & & 1
\end{tabular}


Table 3. Continued.

\begin{tabular}{|c|c|c|c|}
\hline Family & Species & \# spp. & \# individuals. \\
\hline \multirow[t]{20}{*}{ Chrysomelidae Latreille } & Antitypona Weise & 2 & 4 \\
\hline & Aristobrotica Bechyne & 1 & 1 \\
\hline & Brachypnoea Gistel & 1 & 1 \\
\hline & Colaspis Fabricius & 1 & 9 \\
\hline & Coroicona danieli Bechyne & & 9 \\
\hline & Diabrotica Chevrolat & 7 & 17 \\
\hline & Griburius auricapillus (Suffrian) & & 1 \\
\hline & Griburius Haldeman & 2 & 4 \\
\hline & Hecataeus Jacoby & 1 & 20 \\
\hline & Hypolampsis Clark & 1 & 1 \\
\hline & Lexiphanes Gistel & 1 & 1 \\
\hline & Lilophaea Bechyne & 1 & 1 \\
\hline & Luperodes Motschulsky & 1 & 4 \\
\hline & Neothona Bechyne & 1 & 2 \\
\hline & Nycterodina Bechyne & 2 & 2 \\
\hline & Parchicola elena Bechyne & 1 & \\
\hline & Pseudochlamys Lacordaire & 2 & 2 \\
\hline & Sphaeropis Lefevre & 1 & 1 \\
\hline & Spintherophyta Dejean & 2 & 9 \\
\hline & Zepherina Bechyne & 2 & 14 \\
\hline Cleridae Latreille & Enoclerus Gahan & 2 & 30 \\
\hline \multirow[t]{8}{*}{ Curculionidae Latreille } & Contrachelus Dejean & 2 & 7 \\
\hline & Heilipodus Kuschel 1 & 2 & \\
\hline & Heilipodus suspensus (Pascoe) & & 1 \\
\hline & Heilipus phrynodes Pascoe & & 3 \\
\hline & Heilus Kuschel & 2 & 14 \\
\hline & Lechriops (Schoenherr) & 1 & 1 \\
\hline & Pseudanthonomus Dietz & 1 & 3 \\
\hline & Zascelis LeConte & 1 & 1 \\
\hline Dermestidae Latreille & Cryptorhopalum Guerin-Meneville & 2 & 8 \\
\hline Elateridae Leach & Aeolus Eschscholtz & 1 & 1 \\
\hline Lampyridae Rafinesque & Cratomorphus Motschulsky & 1 & 1 \\
\hline Lycidae Laporte & Idiopteron Bourgeois & 1 & 7 \\
\hline \multirow[t]{2}{*}{ Melyridae Leach } & Lemphus bicoloripennis Constantin & & 1 \\
\hline & Lemphus Erichson & 2 & 2 \\
\hline \multirow[t]{4}{*}{ Mordellidae Latreille } & Isotrilophus Liljeblad & 1 & 31 \\
\hline & Mordella signata Champion & & 5 \\
\hline & Mordella Linnaeus & 4 & 7 \\
\hline & Mordellistena Costa & 6 & 18 \\
\hline \multirow[t]{8}{*}{ Scarabaeidae Latreille } & Barybas Blanchard & 2 & 3 \\
\hline & Isonychus Mannerheim & 2 & 4 \\
\hline & Macraspis festiva Burmeister & & 4 \\
\hline & Macraspis nr. maculata Burmeister & & 1 \\
\hline & Macraspis MacLeay & 3 & 4 \\
\hline & Pelidnota osculatii Guerin-Meneville & & 7 \\
\hline & Pelidnota MacLeay & 1 & 2 \\
\hline & Tomarus ebenus (De Geer) & & 1 \\
\hline \multirow[t]{2}{*}{ Tenebrionidae Latreille } & Goniadera repandra Fabricius & & 1 \\
\hline & Statira interruptecostata Pic. & & 1 \\
\hline
\end{tabular}



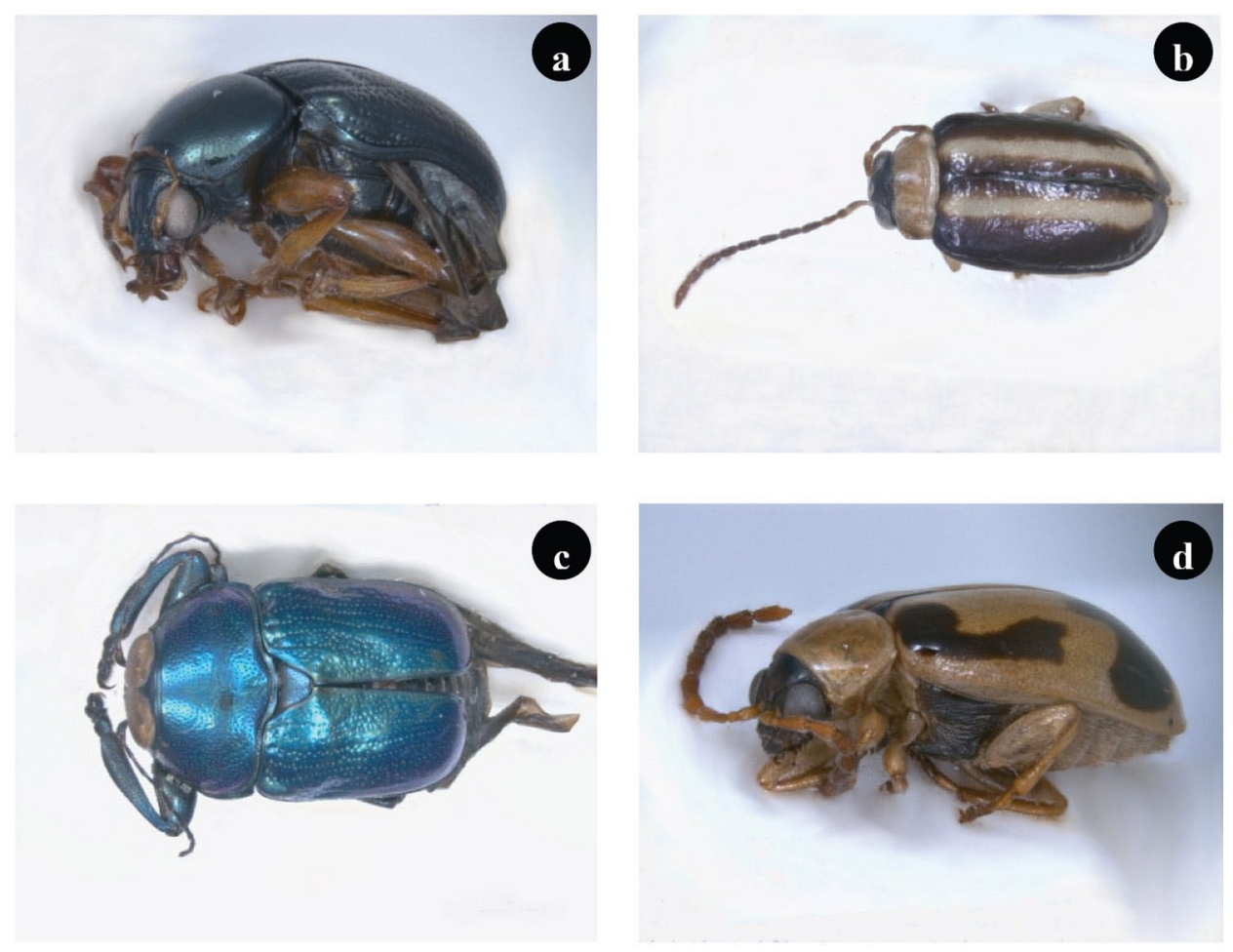

Figure 3. Diversity of Chrysomelidae beetles visiting flowers of Hymenopus heteromorphus (Benth.) Sothers and Prance var. heteromorphus (Chrysobalanaceae), March 1999. (a) Colaspis Fabricius (Eumolpinae). (b) Coroicona danieli Bechyne (Alticini). (c) Griburius auricapillus (Suffrian) (Cryptocephalinae). (d) Hecataeus Jacoby (Galerucinae).

Thirty-one beetle species were found exclusively on our single $H$. heteromorphus tree; seven beetle species were collected with at least two individuals. Furthermore, 72 species were found to visit flowers of tree species with diverse flower syndromes within the study area. Thus, there are 103 out of 138 species (74.6\%) that are restricted in their records to flowers in our canopy plot, including 73 species (52.9\%) restricted to small white flowers of the generalist syndrome. A similar relation is obvious if only the 17 most abundant species (collected with at least three individuals with the window trap or with eight individuals collected per hand) are considered (Table 2). Only one species, Coroicona danieli Bechyne (Chrysomelidae: Galerucinae: Alticini; Figure $3(b)$ ), was found exclusively on $H$. heteromorphus. Eight of these 17 abundant species visited different tree species with small white flowers of the generalist syndrome. Another five abundant species visited 
flowers of different syndromes, whereas three beetle species fed on different plant resources in our canopy plot. In conclusion, the portion of exclusive flower visitors among the abundant species is $82.4 \%$, including $52.9 \%$ visitors of only generalist flowers.

\section{The flower-visiting beetle community of canopy plot}

The beetle fauna collected on our target 23 canopy tree species comprised 6698 adults that are identified to 859 beetle species in 44 families. During the survey period (1997-1999), 20 of the investigated tree species flowered at least once. Of the 859 beetle species sampled, 647 species (75.3\%) were collected with at least one specimen on a flowering tree species (Table 4). Of these 647 beetle species, 527 species (61.4\% of the entire assemblage) were sampled exclusively on flowering trees. Three hundred and fourteen (59.6\% of all exclusive flower visitors) of these flower visitors were sampled exclusively on canopy trees with small white flowers of the generalist syndrome though this flower syndrome was represented only in $35 \%$ of the investigated tree species. The proportion of beetle species visiting exclusively white generalist flowers is $36.6 \%$ of our entire canopy beetle community corresponding to the proportion of this flower syndrome in our survey.

Table 4. Monitored tree individuals $(\mathrm{N}=45)$ and tree species $(\mathrm{N}=23)$ and their associated Coleoptera species in a lowland rainforest canopy, Venezuela, 1997-1999.

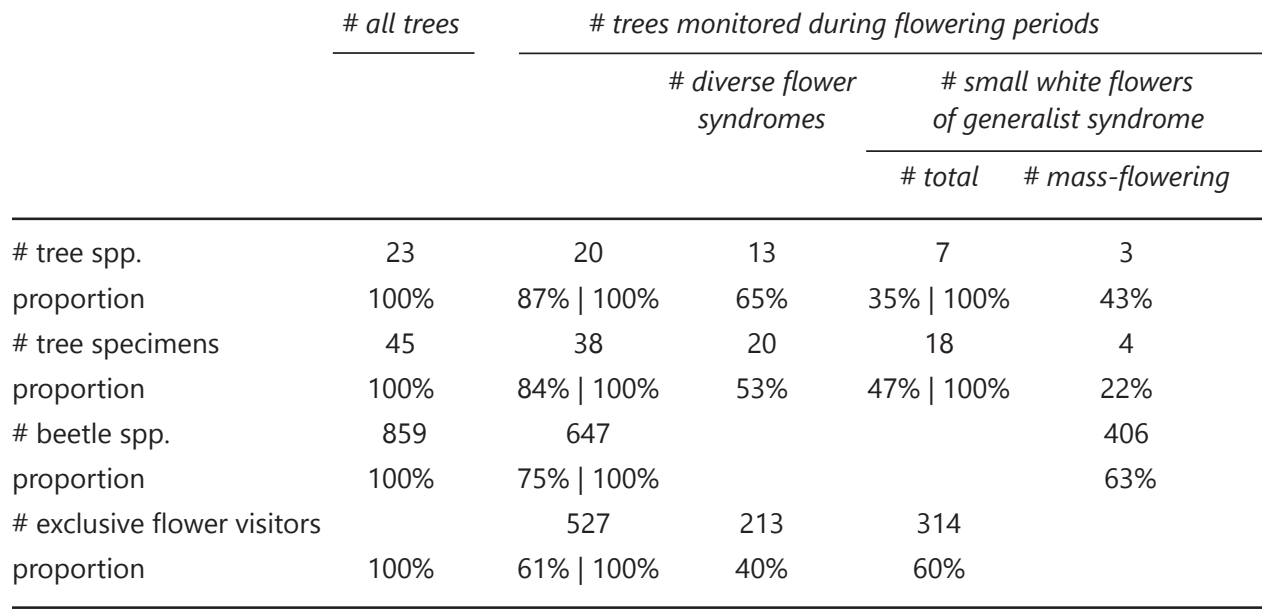


The exclusive 527 flower-visiting beetle species belong to 41 families (Figure 4). The top three families are Curculionidae $(\mathrm{N}=$ 161), Cerambycidae $(N=68)$ and Chrysomelidae $(N=64)$ which correspond to the largest herbivorous clades of beetles. Surprisingly, the next dominant families comprising $10+$ exclusive species on flowering trees are Carabidae $(\mathrm{N}=22)$, Mordellidae $(\mathrm{N}=22)$, Scarabaeidae $(N=20)$, Tenebrionidae $(N=19)$, Staphylinidae $(N=$ $17)$, Nitidulidae $(N=15)$, Coccinellidae $(N=13)$ and Dermestidae $(N=10)$. Most beetle species collected exclusively on white flowers of the generalist syndrome belong to Curculionidae $(N=105)$, Cerambycidae $(\mathrm{N}=53)$, Chrysomelidae $(\mathrm{N}=31)$, Mordellidae $(\mathrm{N}=$ $15)$ and Staphylinidae $(\mathrm{N}=12)$.

\section{Beetle assemblages on mass-flowering trees}

Mass-flowering trees of the generalist syndrome revealed the highest diversity of beetle species sampled on flowering trees in our canopy plot (Table 4). In total, 406 flower-visiting beetle species (63\%) were collected on only three out of 20 flowering tree species. Among them there are 260 beetle species (1446 individuals) collected during three different flowering periods on two tree specimens of $M$. guianensis. This was the highest number of beetle species collected on one tree species within our canopy plot. However, the trap sample on one tree specimen in the main flowering season from 18 September to 8 October 1997 (21 days) with estimated one million flowers amounted to 115 species and 534 individuals (detailed data: Kirmse et al. 2003). Additionally, 65 species were hand-collected on this single tree (Table 5).

On T. guianensis, 114 beetle species (638 individuals) were collected during one flowering period. We estimate the number of flowers between 10,000 and 100,000 from 8-27 November 1997 (18 days) (detailed data: Kirmse et al. 2003). The trap collected 622 individuals in 104 species amounting to an average of 5.8 different beetle species per day (Table 5). This contrasts the trap sample with only 0.4 different species per day during a non-flowering season on this tree species. Taking all beetle species collected on T. guianensis into consideration, just eight species were found during both the flowering and the nonflowering season. 


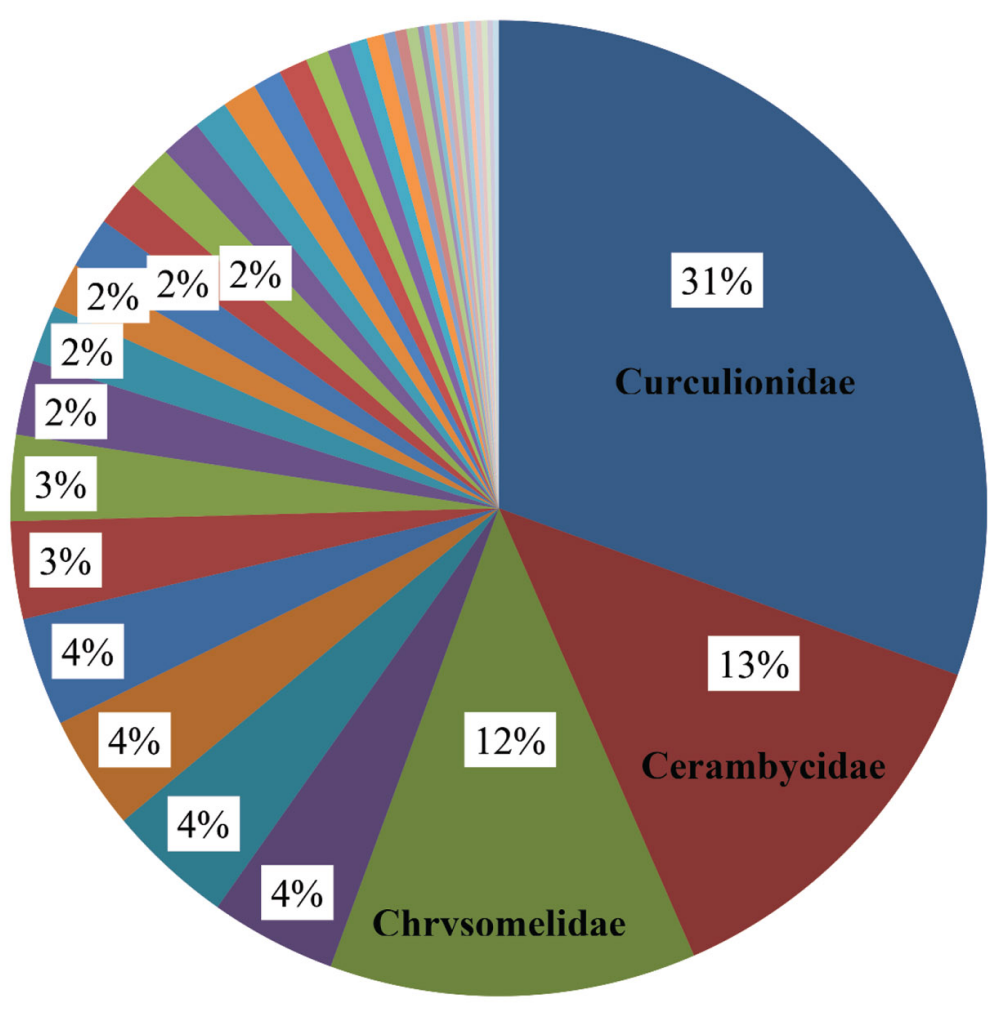

- Curculionidae 161 spp. —Cerambycidae 68 spp. " Chrysomelidae 64 spp.

- Carabidae 22 spp. $\quad$ Mordellidae 22 spp. $\square$ Scarabaeidae 20 spp.

- Tenebrionidae 19 spp. $\quad$ Staphylinidae 17 spp. $\quad$ Nitidulidae 15 spp.

- Coccinellidae 13 spp. $\quad$ Dermestidae 10 spp. Brentidae 8 spp.

- Cantharidae 9 spp. $\quad$ Buprestidae 8 spp. $\quad$ Anthribidae 8 spp.

Eucnemidae 7 spp. $\square$ Elateridae 6 spp. $\square$ Scirtidae 6 spp.

- Cleridae 5 spp. $\quad$ Melyridae 5 spp. $\quad$ Hybosoridae 4 spp.

- Trogossitidae 4 spp. $\square$ Oedemeridae 3 spp. Anobiidae 3 spp.

Histeridae 2 spp. $\square$ Corylophidae 2 spp. $\square$ Meloidae 2 spp.

$\square$ Zopheridae $1 \mathrm{sp.} \quad \square$ Ptilodactylidae $1 \mathrm{sp} . \quad \square$ Scraptiidae $1 \mathrm{sp}$.

$\square$ Aderidae $1 \mathrm{sp.} \quad \square$ Lycidae $1 \mathrm{sp.} \quad$ Leiodidae $1 \mathrm{sp.}$

$\square$ Passalidae $1 \mathrm{sp} . \quad \square$ Elmidae $1 \mathrm{sp} . \quad \square$ Endomychidae $1 \mathrm{sp}$.

Cryptophagidae $1 \mathrm{sp}$. $\square$ Cucujidae $1 \mathrm{sp} . \quad \square$ Erytolidae $1 \mathrm{sp}$.

Hydrophilidae $1 \mathrm{sp}$ Attelabidae $1 \mathrm{sp}$.

Figure 4. Species-level taxonomic diversity of exclusively flower-visiting beetles sampled on 20 canopy tree species (38 individuals) from 12 families in a lowland rainforest canopy, Venezuela, 1997-1999. 
Table 5. Monitored mass-flowering trees $(N=3)$ with small white flowers of the generalist syndrome and their number of associated Coleoptera species and specimens documented in a lowland rainforest canopy, Venezuela. Tag numbers (\#) are for individual trees in rainforest canopy plot, Venezuela.

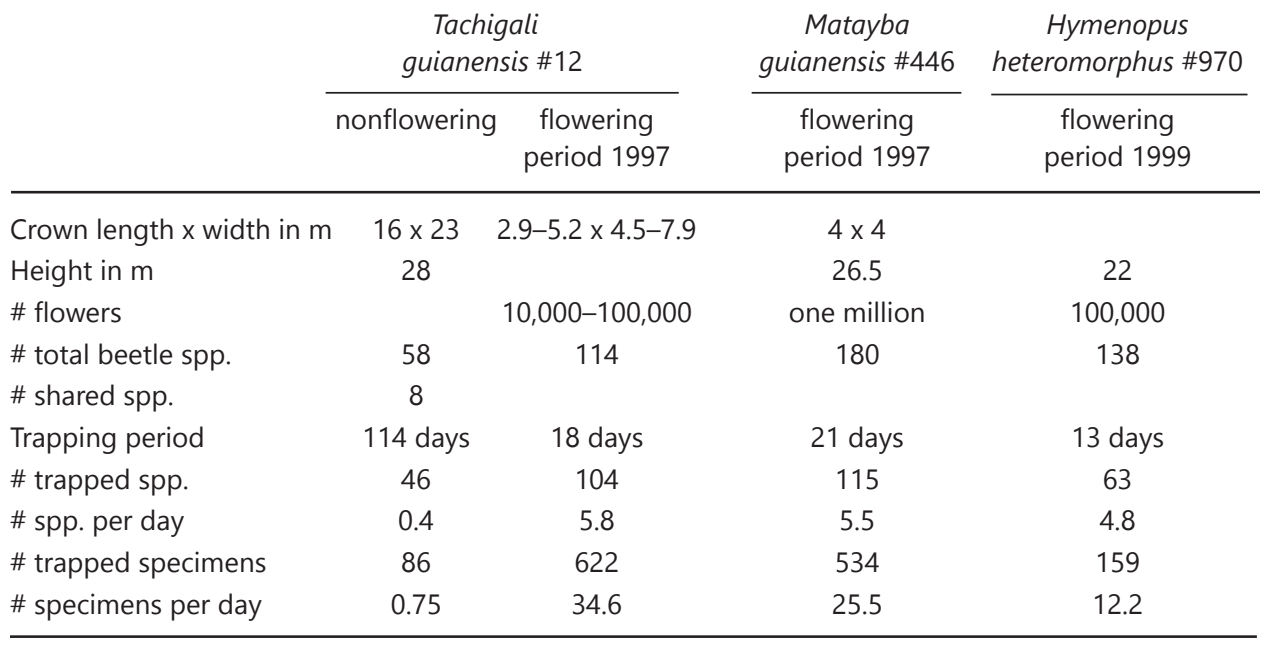

Rich flower-visiting beetle assemblages were also recorded on other canopy trees - A. pedicellaris, G. glabra, O. aff. amazonica, P. loranthoides, Q. paraensis and S. cf. silvestris.

\section{Comparison of the beetle assemblages}

The comparison of the total samples of the three species of Chrysobalanaceae (Table 1; Kirmse and Chaboo 2019: Tables 3 and 4) revealed that four beetle species occurred on all three host trees. Hymenopus heteromorphus and $M$. subarachnophylla shared additionally six species and $H$. heteromorphus and $L$. hebantha shared additional four species. Consequently, the similarity measured with the Jaccard index is $4.9 \%$ and with the Bray-Curtis coefficient $4.4 \%$ between $H$. heteromorphus and L. hebantha and between $\mathrm{H}$. heteromorphus and M. subarachnophylla both values are $5.9 \%$.

Whereas the diversity indices of the total samples of M. subarachnophylla and L. hebantha are similar (3.58 and 3.32), the Shannon index for the total sample of $H$. heteromorphus is 4.13. However, the estimation of species richness varies with 65 species to expect on $L$. hebantha, 94 on M. subarachnophylla, but 372 species are expected to visit $H$. heteromorphus. 
The Shannon diversity based on the trap samples for M. guianensis is 3.54 , for $T$. guianensis 3.23 and 3.29 for $H$. heteromorphus. The number of expected species based on the trap samples is 188 for $M$. guianensis, 267 for $T$. guianensis and 173 for $H$. heteromorphus. Finally, the expected number of species of these three mass-flowering tree species is 546 species based on altogether 228 different beetle species sampled with the traps.

\section{Discussion}

The one-year survey of 23 canopy tree species resulted in the collection of 6698 adult beetles that were identified to 859 species in 44 families (Kirmse unpubl. data; Kirmse and Chaboo 2019: Table 2). Several previous studies of beetles and tropical trees (Irvine and Armstrong 1990; Sakai et al. 1999; Kirmse et al. 2003; Odegaard and Frame 2007; Wardhaugh et al. 2013; Kirmse and Chaboo 2018; Kirmse and Ratcliffe 2019) are referenced frequently below as we discuss our results to identify general and specific patterns of beetle visitation to canopy flowers. Our studies of the flower-visiting beetle fauna of two tree species, M. guianensis and T. guianensis (Kirmse et al. 2003), and the role of extrafloral nectaries for canopy beetles (Kirmse and Chaboo 2019) are also central to this discussion. Below, we focus on the broad community of beetles found at canopy flowers and, in particular, at canopy flowers of one individual target tree $\# 970$ of $H$. heteromorphus (Chrysobalanaceae).

To evaluate our findings, we review common flower-visiting beetle families. We analyze typical patterns of beetle visitation to flowers, especially at mass-flowering canopy trees. We calculate the proportion of canopy beetles utilizing flower resources to test our hypothesis 1. Then we determine the specificity of our canopy beetles to flower resources to test our hypothesis 2 . Finally, we discuss the interactions between the plant and the beetles. As flower-visiting beetles are involved in mutualistic interactions with their host plants we discuss the role of beetles in pollination. The majority of our flower-visiting canopy assemblage seems to be specialized in generalist flowers so we discuss the possible co-evolution between these specialized beetles and their generalist flowers. 


\section{Sample size and specificity}

Our canopy beetle assemblage includes samples from different phenological seasons of the investigated 23 canopy tree species (Table 4). The data set includes beetles collected during the flowering season of 20 different tree species and 38 specimens. We included a broad spectrum of tree families $(\mathrm{N}=12)$ with diverse flower syndromes to collect a wide range of flower-visiting beetle species. This cross-section of the 141 tree species represents with a portion of $14 \%$ a good data basis for an estimation of the flower-visiting beetle fauna in our canopy plot.

The portion of tree species with small white flowers of the generalist syndrome is only $35 \%$ of all flowering tree species. Nevertheless, $59.6 \%$ of all exclusive flower visitors were restricted to this flower syndrome during our survey, thus emphasizing the importance of this flower syndrome as food resource for Amazonian canopy beetles. Although the sampling effort is not equal for all investigated trees and flowering seasons differ between tree species, the standardized trap samples provide a valid base to compare the species richness and diversity between different trees.

We included all beetle species independent of their abundances in our evaluation of the resource use. This seems justified mainly due to two reasons. First, our traps sampled only in a small area of tree crowns and so collected only a part of the beetle assemblage. Also, hand collection covered only a small part of the investigated tree crowns. As a result, overall abundances are low compared to the dimension of a tree crown of our investigated trees. The second reason is that flower-visiting beetle species do not reside on the trees. They are restricted in their occurrence to the flowering season and moreover restricted either to day- or night-time (Kirmse et al. 2003). Thus, singletons are considered to be part of the flower-visiting assemblage.

\section{Flower-visiting beetle families}

Worldwide flower visitation has been documented in 60 beetle families and 40 of these families are regularly associated with flowers (Wardhaugh 2015). We greatly contribute to that list as our collections reveal 647 beetle species in 44 families at flowering tree species in the Surumoni canopy plot. These data firmly indicate that a diversity 
of beetles consumes flowers resources. Most of our species were collected exclusively on our canopy flowers (Figure 4). The patterns of beetle visitation found in our dataset are congruent with those of previous studies. We found Curculionidae and Chrysomelidae as our most frequent flower visitors to $H$. heteromorphus and to T. guianensis (Kirmse et al. 2003); these two large beetle families appear to be the dominant flower visitors in most tropical forests (Momose et al. 1998; Sakai et al. 1999; Kato et al. 2008). However, the species richness of our sampled Cerambycidae surpassed those of Chrysomelidae on M. guianensis (Kirmse et al. 2003) as well as in our entire canopy assemblage, and echoes that found on canopy trees in Panama (Odegaard and Frame 2007). Another established pattern of common flower-visiting beetles of Dermestidae, Nitidulidae and Scarabaeidae (Kuchmeister et al. 1997; Momose et al. 1998; Sakai et al. 1999; Kato et al. 2008) was also reflected in our data for the entire canopy assemblage.

The Surumoni canopy beetle assemblage revealed many flower-visiting Staphylinidae, agreeing with that reported by Frame (2003) and reviewed by Sayers et al. (2019). We found Mordellidae as one dominant beetle family on our $\mathrm{H}$. heteromorphus, and they were numerous on M. guianensis (Kirmse et al. 2003). Our species-rich flower-visiting families Carabidae, Coccinellidae, Mordellidae and Tenebrionidae (Figure 4) are known as flower visitors (Grinfeld 1975; Olesen 1992; Sakai et al. 1999; Bernhardt 2000; Jackman and Lu 2002). Species of many other beetle families are described as flower visitors and our findings support this (Figure 4): Anthribidae (Proches and Johnson 2009); Brentidae (Kuchmeister et al. 1997; Odegaard and Frame 2007); Buprestidae (Hawkeswood 1978); Cantharidae (Willson and Bertin 1979; Zepeda-Gomez and Velazquez-Montes 1999); Cleridae, Melyridae and Oedemeridae (Grinfeld 1975); Corylophidae and Cryptophagidae (Sakai et al. 1999); Elateridae and Lampyridae (Dayanandan et al. 1990); Erotylidae and Phalacridae (Britton 1970); Hydrophilidae and Scraptiidae (Bernhardt 2000); Lycidae (Irvine and Armstrong 1990); and Meloidae (Goldburg 1987).

\section{Patterns of beetle visitation to flowers}

The occurrence of beetles on our $\mathrm{H}$. heteromorphus was restricted to the flowering season, with 440 beetles sampled in 25 February-16 
March. Beetles do not appear to be attracted to $H$. heteromorphus before flourishing of nor after wilting of the flowers. This seems a general pattern that fits with other studies. Some species, especially Eumolpinae leaf beetles, were found associated with the presence of flowers in Papua New Guinea (Basset and Samuelson 1996). Kirmse et al. (2003) demonstrated previously that highest abundances of beetles caught by the window trap coincided with peak flowering of M. guianensis and T. guianensis. This is congruent with other studied tropical trees. In Xylopia L. (Annonaceae) in Brazil, visitors became abundant with peak flowering season but not before (Andrade et al. 1996). Capture rates of pollen-feeding beetles within the canopies of Myristica insipida R.Br. (Myristicaceae) in an Australian tropical rainforest were positively related to the number of open flowers, which varied throughout the day (Armstrong 1997). All these studies show that flower-visiting beetles are strongly linked to this food resource indicating the specificity of these beetles.

The beetles we sampled visited the flowers of $H$. heteromorphus either during the day or during the night, so species exhibit distinct temporal visitation. This may depend on intrinsic diel activity phases of the flower-visiting beetles and/or on the anthesis characteristics of the flowers. Anthesis in Xylopia flowers, for instance, starts at $5.30 \mathrm{~h}$ and all flowers are open at $8.00 \mathrm{~h}$ (Andrade et al. 1996). The rewards are often available only for a short period. In Miconia theizans (Bonpl.) Cogn. (Melastomataceae), visitation started in the morning with the sunrise and continued until around $14.00 \mathrm{~h}$ when the flowers started to wilt (Vinicius et al. 2017). Beetle visitors of mass-flowering trees with white generalist flowers such as $H$. heteromorphus, M. guianensis or T. guianensis were dominated by diurnal species and individuals (Kirmse et al. 2003). On two trees with comparable flowering syndrome and appearance in Panama, Odegaard and Frame (2007) found the highest beetle activity from 7:30 h to 10:00 h. Thus, flower-visiting assemblages of beetles are distinct in time and location.

Our observations that mass-flowering trees in our plot attract both the highest diversity (i.e. number of species) and abundance (i.e. number of individuals) of flower-visiting beetles are congruent with a widely-documented phenomenon for a high diversity of often opportunistic visitors (Augspurger 1980; Newstrom et al. 1994). Irvine and Armstrong (1990) recorded the same phenomenon from two 
different tree species with small generalist flowers in the Australian tropical rainforest. Wolda et al. (1998) captured many Curculionidae and Brentidae on one mass-flowering Tachigali versicolor Standl. and L.O. Williams (Fabaceae) in Panama. Odegaard and Frame (2007) investigated similar generalist blossoms of Nectandra umbrosa (Kunth) Mez. (Lauraceae) and Tapirira guianensis Aubl. (Anacardiaceae), two canopy trees in a wet Panamanian lowland forest and they collected 723 beetles representing 121 species from N. umbrosa and 841 beetles representing 121 species from $T$. guianensis. These assemblages in the studies of Augspurger (1980), Irvine and Armstrong (1990), Wolda et al. (1998) and Odegaard and Frame (2007) are comparable with our samples of $H$. heteromorphus, M. guianensis and T. guianensis. Thus, we believe it may be a generality that mass-flowering tropical trees attract both high diversity and high abundance of flower-visiting beetles. We predict this phenomenon should be widespread and frequent as mass-flowering often occurs in canopy trees and lianas including about $70 \%$ of overstorey trees in wet forests (Frankie et al. 1974).

\section{How many beetles visit flowers?}

Wardhaugh et al. (2012) reported that flowers are utilized by approximately $41 \%$ of the beetle species in an Australian tropical rainforest. We found $75.3 \%$ of our sampled beetle species represented at least by one individual on flowering trees. Considering only beetle species collected exclusively on flowering trees then $61.4 \%$ of all beetle species of our entire canopy assemblage are associated with flowers. This highly supports our hypothesis 1 that the majority of adult canopy beetles subsist on flowers. Of course, we included trap samples in our calculation containing beetle species without feeding observations as well. Still, we demonstrate that flower-visiting beetle assemblages are discrete in time and location. Some beetle species attracted could be predatory, but we found predatory beetle groups to feed on flowers as well. Other beetle taxa such as Buprestidae, Curculionidae or Nitidulidae use flowers for oviposition (Burke 1976; Crowson 1981; Armstrong and Marsh 1997; Oliveira Lourenco et al. 2017), but adults were found feeding on the flowers themselves.

Our canopy sample includes predominantly beetles collected from vegetative parts of the trees and smaller twigs. In contrast, other 
studies using fogging of trees revealed all beetles associated with trunks, branches, epiphytes, phytotelmata etc. from nearly all forest layers (Erwin 1995; Miller et al. 2002; Basset et al. 2003a; Gasca and Higuera 2010) and thus including, for instance, also fungivorous or xylophilous beetle species. The proportion of flower visitors of all beetle species associated with a rainforest tree might be indeed lower than our result; however, we sampled 527 beetle species exclusively on flowering trees of 20 tree species. This amounted to an average of 26.35 flower-visiting beetle species per investigated tree species. For the 141 tree species in our crane plot we extrapolate up to 3715 flower-visiting beetle species. Considering the 3189 tree species known from the Venezuelan Amazon (Ter Steege et al. 2016), then the number of flower-visiting beetle species in the area amounts to 84,030 . Taking the total of estimated 16,000 Amazonian tree species (Ter Steege et al. 2016) there could be 421,600 beetle species utilizing flowers on Neotropical tree species in the Amazonian rainforest alone.

These calculations are supported in our analysis of the samples of the three species of Chrysobalanaceae. There was slight overlap of 14 beetle species between those associated with extrafloral nectaries and those associated with flowers. Keeler (1977) found this also in Ipomoea carnea Jacq. (Convolvulaceae) where the visitor fauna to flowers and extrafloral nectaries was completely different. The different composition of beetle communities visiting either extrafloral nectaries or flowers suggests that flower-visiting beetle assemblages are largely recruited from a distinct species pool. Wardhaugh et al.'s $(2012,2013)$ analyses of the distribution of beetles between different food resources in the Australian rainforest concur with our findings and revealed that flowers support a unique and remarkably rich beetle fauna compared to leaves. Based on our entire sample of 138 beetle species collected, the estimation of the species richness on $\mathrm{H}$. heteromorphus revealed a potential 372 species. The expected number of beetle species associated with all three mass-flowering trees with generalist flower syndrome based on 228 trapped flower visitor species is 546. This together indicates that the real number of flower-utilizing beetle species likely exceeds the number of other beetle guilds (e.g. leaf feeders) on a rainforest tree and in the rainforest canopy at all, by far. Thus, we see strong evidence for our hypothesis 1 that the megadiversity of canopy beetles in tropical rainforests is largely based on flower resources. 


\section{The beetle-flower interface}

Beetles have been reported as dominant flower visitors in different ecosystems (Smith- Ramirez et al. 2005; Gomez et al. 2007; Reverte et al. 2016; Valverde et al. 2019), and they have been long recognized as important Angiosperm pollinators (Gottsberger 1990; Bernhardt 2000; Thien et al. 2009). Many Cantharidae, Cerambycidae, Chrysomelidae, Curculionidae, Elateridae, Melyridae, Mordellidae, Nitidulidae, Scarabaeidae and Staphylinidae carry pollen on their bodies (Bernhardt 1989; Lamborn and Ollerton 2000; Willmer 2011; Gottsberger 2016; Koptur and Khorsand 2018; Sayers et al. 2019); these are numerous in our canopy assemblage. Several of our abundant beetle species exhibited flower constancy (Kirmse and Chaboo 2018; Kirmse and Ratcliffe 2019; Kirmse and Johnson 2020); for example, such as reported by Englund (1993) for Cetoniinae (Scarabaeidae) and enhance the probability of carrying pollen between conspecific trees. Visitor abundance is often used as a measure of pollination outcomes (Olsen 1997) because the number of flower visitors is strongly correlated with the number of pollinators and therefore can serve as an appropriate proxy (Ollerton and Cranmer 2002; Biella et al. 2019). Visitation rates play a more important role in plant reproduction than effectiveness (Vazquez et al. 2005, 2015; Sahli and Conner 2006; Ballantyne et al. 2017; Koptur and Khorsand 2018). According to the numerous beetles that visited our three mass-flowering trees, H. heteromorphus, M. guianensis and $T$. guianensis, Coleoptera should be considered as important pollinators in these tree species. This contrasts with the traditional expectation of Bawa et al. (1985) that beetle-pollinated canopy trees are rare in lowland Neotropical wet forests.

Our data suggest that particularly canopy flowers of the generalized morphology represent an important source of food for beetles. In these systems, beetles possibly represent a dominant pollinator group (Kirmse et al. 2003; Odegaard and Frame 2007). Generalist flowers pollinated by a combination of beetles are recorded in 22 plant families (Bernhardt 2000). These flowers may thus play an important role in the conservation of the biodiversity of flower-visiting insects in general (Frame 2003; Montoya et al. 2012). Such plants could serve as hubs in the interaction networks (Martin Gonzalez et al. 2010; Goldstein and Zych 2016; Watts et al. 2016) and support high visitation in the plant communities (Biella et al. 2019). This clearly applies to our $H$. 
heteromorphus along with M. guianensis and T. guianensis that exhibit a rather generalized morphological flower syndrome with small whitish flowers which offer pollen and nectar. In addition, many flowers without the cantharophilous and generalist syndrome, respectively, are known to be visited by beetles (Kevan and Baker 1983; Ollerton et al. 2003). In our canopy plot, particularly flowers of $A$. pedicellaris, G. glabra or Q. paraensis attracted numerous beetles. We found a proportion of $40.4 \%$ of exclusive flower-visiting beetle species visiting flowers with different syndromes. A possible reason could be that the cantharophilous syndrome encompasses a broad range of floral structures, which overlap with those of a number of other flower syndromes (Irvine and Armstrong 1990). We conclude that many Amazonian canopy tree species with different flower syndromes attract numerous beetles; these beetles in turn play an important role in pollination of these Amazonian canopy tree species.

\section{How general are generalist flowers and their visitors?}

'Generalization' in the definition of pollination ecologists correlates with the number of pollinators and flower visitors, respectively (Waser et al. 1996; Ollerton et al. 2007), but it does not concern the flower morphology (Ollerton et al. 2007). This ecological generalization applies to our target trees, H. heteromorphus, M. guianensis and $T$. guianensis, which represent at the same time the classical generalist syndrome with radially symmetrical flowers providing open access to reward their visitors. The combination of morphological generalism and visitor generalism can be found in a wide range of plant families (Ollerton et al. 2007).

As the species richness and specifically in beetles is highest in low latitudes (Pianka 1966; Stork 1988; Gaston et al. 1995) there is a significant positive relationship between latitude and number of pollinators/ flower visitors per plant species (Ollerton and Cranmer 2002). As a result, plant-pollinator interactions are not more ecologically specialized in the tropics compared to temperate latitudes (Ollerton and Cranmer 2002; Ollerton 2012; Schleuning et al. 2012). A comparison of the flower-visitor generalization level $L$ of a flowering plant species $n$ which is defined as the number of flower-visiting animal species attracted to the flowers of $n$ in a given study site (Olesen et al. 2007) 
will demonstrate that. The average generalization level $L$ of our $H$. heteromorphus in beetle species alone was 138. The most generalized plant found by Kato et al. (1990) was the dish-bowled temperate herb Anthriscus sylvestris (L.) Hoffm. (Apiaceae) with $L=188$. Among 1,403 flowering plant species, Olesen et al. (2007) calculated an average generalization level $L$ of 9.7. We found a value of 26.35 on 20 canopy trees indicating a higher level of generalization. However, the generalization level also depends upon the size and taxonomic composition of the local visitor fauna (Olesen 2000). Thus, $L$ also increases with the number of flower-visitor species $A$ within a study site (Olesen et al. 2007). To compare study sites, the relative generalization level was used and amounted to $50-70 \%$ in the top-10 most generalized plant species (Olesen et al. 2007). L/A is the proportion of the total flower-visitor fauna in a study site that visited a given plant species. In $H$. heteromorphus this value is about $21 \%$, but during three flowering seasons of $M$. guianensis it amounts to about $40.2 \%$. This suggests that a significant smaller percentage of our local flower visitor pool visited our mass-flowering tree species in comparison to the study of Olesen et al. (2007).

\section{Specialization to generalization}

It is generally acknowledged that generalist plants provide floral resources to a wide range of animal species visiting their flowers, and generalist pollinators carry pollen of many plant species (Biella et al. 2019). According to Ollerton et al. (2007), these systems are mainly pollinated by the most abundant visitors in any one year, and this can fluctuate greatly. The annual fluctuations in pollinator abundances that are a feature of many plant-pollinator systems (Herrera 1988; Pettersson 1991; Fishbein and Venable 1996; Lamborn and Ollerton 2000) suggest that a time scale of years to decades may be necessary to record all pollinators for generalist pollination systems (Ollerton and Cranmer 2002). Furthermore, complete sampling requires nocturnal and diurnal observations over the whole flowering season (Ollerton et al. 2006), as author SK has done herein. Despite these efforts, our estimation of the potential number of flower visitors of 372 species on $H$. heteromorphus indicates that there are many more possible beetle visitors. Thus, flowers of $H$. heteromorphus are likely 
mostly visited randomly and not associated with a species-specific visitor spectrum. Host-specific species like the leaf beetle C. danieli are probably the exception.

There is obviously rarely a species-specific adaptation of beetles to their flowers, yet $61.4 \%$ beetle species in our canopy assemblage fed exclusively on flower resources and were found only associated with the presence of flowers. Particularly many Cerambycidae and Curculionidae but also all species of our Mordellidae and Dermestidae visited flowers. Of all exclusive flower-visiting beetle species, 59.6\% were specialized in small white flowers of the generalist syndrome. This particularly applies to many of our Cerambycidae, Mordellidae and Staphylinidae comprising more than half of species restricted to these flowers. This strongly supports our hypothesis 2 that the majority of canopy beetles are adapted flower visitors. Certain taxa exhibit adaptations to feed on pollen and nectar (Figure 1).

The large portion of our specialized canopy beetles suggests there could be a strong mutualistic interaction between these beetles and their flowers. Floral specialization is interpreted as a reasonable correspondence between the set of floral traits and the identity of specific and most effective pollinators (Stebbins 1970; Fenster et al. 2004; Rosas-Guerrero et al. 2014). Hymenopus heteromorphus could be adapted to diverse beetles along with other insects. Consequently, the generalist flower syndrome in rainforest canopy trees indicates fluctuating pollinators. Gottsberger and Silberbauer- Gottsberger (2018) also found this pattern in many Brazilian cerrado plants where generalist, polyphylic flowers were visited by fluctuating pollinator groups. Sharing similar pollinators like our diverse flower-visiting beetles might drive convergence of floral traits (Fenster et al. 2004). General nectar properties and particularly sugar composition are commonly similar between plants with the same visitors - even in unrelated plant species (Baker and Baker 1982, 1983; Nicolson and Thornburg 2007). Plants pollinated by a similar guild of animals appear to have evolved similar visual (Fenster et al. 2004) and olfactory signals (Knudsen and Tollsten 1993; Dobson 2006). Sharing pollinators could represent an advantage for the canopy trees as a single tree species would not be able to support a diversified, abundant and functional pollinator community on its own (Pornon et al. 2019). Moreover, decreasing the dependence on specific pollinators may stabilize pollination over 
broad temporal and spatial scales (Brosi 2016). As the flowers provide a diet rich in nutrients and low in toxic substances it promotes a generalized flower fauna of a particular plant species (Samuelson 1989; Jolivet and Hawkeswood 1995). Indeed, often many different flower-visiting beetle taxa of the same beetle families share the same range of plant species and visit several plant species (Momose and Inoue 1994; Corlett 2004).

It is important for the generalist flower of our canopy trees to attract a broad spectrum of visitors because visitor abundances may change annually (Pettersson 1991; Fishbein and Venable 1996; Alarcon et al. 2008) due to the competition for pollinators with other plants. We found this in several species of Chrysomelidae (Kirmse and Chaboo 2018), Elateridae (Kirmse and Johnson 2020) and Scarabaeidae (Kirmse and Ratcliffe 2019) where these beetles show preferences for particular plant species. Galetto and Bernardello (2003) argued that the attraction of pollinators depends on alternative nectar sources available. The flower-visiting beetles must deal with flowering seasons which are temporally limited and thus, they need to find the next resource after depletion of the first one as many pollinator species are present all year round in the tropics (Lobo et al. 2003). Many tropical plants often flower without regularity and synchrony (Newstrom et al. 1994; Sakai 2001; Wesenberg 2004) and thus are unpredictable for flower-visiting beetles. We suspect that these two mechanisms of unpredictability may interact such that plants force beetles to generalize and beetles force plants to do the same; this would promote a self-adjusting, self-strengthening and self-maintaining but possibly well co-adapted system in rainforest canopies. The high percentage of beetle species specialized in small white flowers of the generalist syndrome supports this new hypothesis. Such a generalization in pollination systems is apparently widespread (Waser et al. 1996; Gomez and Zamora 2006; Petanidou et al. 2008) and probably common in canopy trees. In the Neotropical rainforest in Costa Rica, generalist flowers pollinated by small diverse insects were more frequent in the canopy compared to the subcanopy and understory (Kress and Beach 1994). Gottsberger and Silberbauer-Gottsberger (2018) found $43 \%$ of the Brazilian Cerrado trees and Araujo et al. (2009) 30.1\% of in the Brazilian Atlantic rainforest trees exhibiting a generalist floral syndrome. 


\section{Possible co-evolution between beetles and generalist flowers}

The prevailing view at present is that the earliest angiosperms were probably generalized in their pollination syndromes and pollinated by insects (Bernhardt and Thien 1987; Bernhardt 2000; Hu et al. 2008; Ollerton 2017). Extant archaic angiosperm flowers are generalist flowers (Frame 2003). Beetle pollination was probably derived from generalist entomophilous ancestors (Gottsberger 1988). This suggests that beetles were among the most numerous and effective pollinators that visited the first generalized entomophilous flowers (Bernhardt and Thien 1987; Bernhardt 2000; Frame 2003; Cardinal and Danforth 2013; Ollerton 2017). From an ecological perspective, generalization has a positive effect as it favors competitive ability (Richardson et al. 2000). This seems to apply to both our investigated trees $-H$. heteromorphus, M. guianensis and T. guianensis - and many of our 314 beetle species which visited only small white flowers of the generalist syndrome but rarely being restricted to one canopy tree species. The generalist syndrome seems to be advantageous under certain circumstances and in different ecosystems. Generalization may result from the evolutionary dynamics of numerous equal pollinating visitors selecting for the same floral features so that selection may favor adding new pollinators without losing any old ones (Aigner 2001).

Today's plant-pollinator mutualisms are the result of $\sim 170$ million years of evolution (Gang et al. 2016), yet extreme specialization remains rare (Waser et al. 1996). Plant-pollinator networks appear to have flower visitors that are mostly generalized in their flower choices (Vazquez and Aizen 2004; Petanidou and Potts 2006). In our sample on $H$. heteromorphus, most beetle species visited different plant species. However, not all beetle taxa visited all flower syndromes. Buprestidae, Cantharidae, Carabidae and Coccinellidae, for example, visit several generalist flowers, but are not associated with exclusive beetle-pollinated flowers (Bernhardt 2000). We found this pattern in the sample on $H$. heteromorphus where Cantharidae were speciose and on $T$. guianensis where Carabidae were speciose (Kirmse et al. 2003). As these beetle families are absent or uncommon in early plant lineages of most magnoliids and basal monocotyledons (Bernhardt 2000) this suggests their late development of flower visitation. In contrast, taxa belonging to the highly diverse beetle families Cerambycidae, 
Curculionidae and Scarabaeidae are most likely to pollinate both specialist and generalist systems and one can predict that they diversified multiple times with their host plants (Bernhardt 2000; Ahrens et al. 2014). Indeed, Scarabaeidae and Cerambycidae were along with Curculionidae speciose on $H$. heteromorphus. Bernhardt (2000) found the same overlap in Cleridae and Mordellidae which were species-rich on our flowering $\mathrm{H}$. heteromorphus.

\section{Conclusions}

The majority of rainforest canopy beetles ( $75.3 \%$ of the 647 species) we documented over the one-year sampling period were associated with flowering trees. The majority of these species (527 species in 41 families) were recorded only on flowers. The flower-visiting beetle assemblages were distinct in time and location and largely represent a distinct species pool in the canopy of the Amazonian lowland rainforest. This together demonstrates evidence to support our hypothesis 1 . We suggest therefore that flowers play a crucial role in the nourishment of tropical rainforest canopy beetles and are likely one of the most important drivers for maintaining the high diversity of beetles in rainforests.

We conclude that the mass-flowering trees with small white flowers of the morphological generalist syndrome attracted the most speciose flower-visiting beetle assemblages. It appears that such resource concentrations support the highest diversity and abundances of beetle species. These tree species therefore play a central role as temporary diversity hotspots in tropical rainforest canopies.

We found that the majority of our exclusive flower visitors (314 species of 527 documented species) only visited small white flowers of the generalist syndrome. This observation strongly supports our hypothesis 2. We conclude that a large portion of Amazonian canopy beetles is specialized in the visitation of this flower syndrome. For that reason, we propose that these generalist flowers and their visitors may represent rather a highly co-evolved interaction and not just a random encounter of visitor taxa.

Our data and their analyses strongly indicate that beetles are an underestimated pollinator taxon. Considering the current rapid decline 
in insect and pollinator communities respectively, understanding plant-pollinator interactions is more critical. Unravelling the complex plant-pollinator interactions in megadiverse rainforest canopies remains a challenge due to difficult access, but this can be overcome with intense detailed study over long periods.

Acknowledgements For the determination of the beetles we thank all the beetle experts indicated in Methods. We cordially thank Jens Wesenberg for superior assistance in all botanical matters and field work. We thank an anonymous reviewer for a valuable evaluation of this study and significant comments on the manuscript. The Austrian Academy of Sciences and colleagues are gratefully acknowledged for their support and permission to join the Surumoni project in Venezuela. The fieldwork of SK was supported by grants from the ESF Tropical Canopy Programme and the Stiftung der Deutschen Wirtschaft, Germany. We dedicate this paper to our colleague and past co-author, Terry Erwin (1940-2020), who challenged biologists to inventory the megadiverse insects of rainforest canopy trees.

Disclosure No potential conflict of interest was reported by the authors.

Funding This work was supported by the ESF Tropical Canopy Programme [travel grant]; and the Stiftung der Deutschen Wirtschaft [3-year fulltime scholarship]; ESF (European Science Foundation) Tropical Canopy Programme (travel grant).

Geolocation information The study site is located in the upper Orinoco region state of Amazonas, Venezuela: $3^{\circ} 10^{\prime} \mathrm{N}, 65^{\circ} 40^{\prime} \mathrm{W}$.

\section{References}

Adis J, Lubin YD, Montgomery GG. 1984. Arthropods from the canopy of inundated and terra firme forests near Manaus, Brazil, with critical considerations on the Pyrethrum-fogging technique. Stud Neotrop Fauna Environ. 19:223-236. https://doi.org/10.1080/01650528409360663

Ahrens D, Schwarzer J, Vogler AP. 2014. The evolution of scarab beetles tracks the sequential rise of angiosperms and mammals. Proc R Soc B. 281:20141470. https://doi.org/10.1098/rspb.2014.1470

Aigner PA. 2001. Optimality modeling and fitness trade-offs: when should plants become pollinator specialists? Oikos. 95:177-184. https://doi. org/10.1034/j.1600-0706.2001.950121.x

Alarcon R, Waser NM, Ollerton J. 2008. Year-to-year variation in the topology of a plant-pollinator interaction network. Oikos. 117:1796-1807. https://doi. org/10.1111/j.0030-1299.2008.16987.x 
Andrade BM, Oliveira-Filho AT, Soares AR. 1996. Pollination and breeding system of Xylopia brasiliensis Sprengel (Annonaceae) in South-eastern Brazil. J Trop Ecol. 12:313-320. https://doi.org/10.1017/S0266467400009482

Anhuf D, Motzer T, Rollenbeck R, Schroder B, Scarzynski J. 1999. Water budget of the Surumoni crane site (Venezuela). Selbyana. 20(1):179-185.

Anhuf D, Rollenbeck R. 2001. Canopy structure of the Surumoni rain forest (Venezuela) and its influence on microclimate. Ecotropica. 7:21-32.

Araujo JLO, Quirino ZGM, Neto PCG, Araujo AC. 2009. Sindromes de polinizacao ocorrentes em uma area de Mata Atlantica, Paraiba, Brasil. Rev Biotemas. 22(4):83-94. https://doi.org/10.5007/2175-7925.2009v22n4p83

Armstrong JA. 1979. Biotic pollination mechanisms in the Australian flora—a review. NZ J Bot. 17:467-508. https://doi.org/10.1080/00288 25X.1979.10432565

Armstrong JE. 1997. Pollination by deceit in nutmeg (Myristica insipida, Myristicaceae): floral displays and beetle activity at male and female trees. Am J Bot. 84:1266-1274. https://doi.org/10.2307/2446051

Armstrong JE, Marsh D. 1997. Floral herbivory, floral phenology, visitation rate, and fruit set in Anaxagorea crassipetala (Annonaceae), a lowland rain forest tree of Costa Rica. J Torrey Bot Soc. 124:228-235. https://doi. org/10.2307/2996610

Arndt E, Kirmse S, Erwin TL. 2001. Arboreal beetles of Neotropical forests: Agra Fabricius, larval description with notes on natural history and behavior (Coleoptera, Carabidae, Lebiini, Agrina). Coleop Bull. 55:297-311. https://doi. org/10.1649/0010-065X(2001)055[0297:ABONFA]2.0.CO;2

Augspurger CK. 1980. Mass-flowering of a tropical shrub (Hybanthus prunifolius): influence on pollinator attraction and movement. Evolution. 34:475-488. https://doi.org/10.1111/j.1558-5646.1980.tb04837.x

Baker HG, Baker I. 1982. Chemical constituents of nectar in relation to pollination mechanism and phylogeny. In: Nitecki MH, editor. Biochemical aspects of evolutionary biology. Chicago: University of Chicago Press; p. 131-171.

Baker HG, Baker I. 1983. Floral nectar sugar constituents in relation to pollinator type. In: Jones CE, Little RJ, editors. Handbook of experimental pollination biology. New York: Van Nostrand Reinhold; p. 117-141.

Ballantyne G, Baldock KCR, Rendell L, Willmer PG. 2017. Pollinator importance networks illustrate the crucial value of bees in a highly speciose plant community. Sci Rep. 7:8389. https://doi.org/10.1038/s41598-017-08798-x

Bao T, Wang B, Li J, Dilcher D. 2019. Pollination of Cretaceous flowers. PNAS. 116(49):24707-24711. https://doi.org/10.1073/pnas.1916186116

Barth FB. 1985. Insects and flowers: the biology of a partner-ship. Princeton: Princeton University Press; p. 297.

Basset Y, Samuelson GA. 1996. Ecological characteristics of an arboreal community of Chrysomelidae in Papua New Guinea. In: Jolivet PHA, Cox ML, editors. Chrysomelidae biology. Volume 2: ecological studies. Amsterdam: SPB Academic Publishing; p. 243-262. 
Basset Y, Springate ND, Aberlenc H-P, Delvare G. 1997. A review of methods for sampling arthropods in tree canopies. In: Stork NE, Adis JA, Didham RK, editors. Canopy arthropods. London: Chapman \& Hall; p. 27-52.

Basset Y, Hammond PM, Barrios H, Holloway JD, Miller SE. 2003a. Vertical stratification of arthropod assemblages. In: Basset Y, Novotny V, Miller SE, Kitching RL, editors. Arthropods of tropical forests. Spatio-temporal dynamics and resource use in the canopy. Cambridge: Cambridge University Press; $p$. $17-27$.

Basset $Y$, Horlyck V, Wright SJ. 2003b. Forest canopies and their importance. In: Basset Y, Horlyck V, Wright SJ, editors. Studying forest canopies from above: the international Canopy crane network. Panama: Smithsonian Tropical Research Institute and UNEP; p. 27-36.

Bawa KS. 1990. Plant-pollinator interactions in tropical rain forests. Ann Rev Ecol Syst. 21:399-422. https://doi.org/10.1146/annurev.es.21.110190.002151

Bawa KS, Beach H. 1981. Evolution of sexual systems in flowering plants. Ann Missouri Bot Gard. 68:254-274. https://doi.org/10.2307/2398798

Bawa KS, Bullock SH, Perry DR, Coville RE, Grayum MH. 1985. Reproductive biology of tropical lowland rain forest trees. II. Pollination systems. Amer J Bot. 72:346-356. https://doi.org/10.1002/j.1537-2197.1985.tb05358.x

Bellamy CL. 1986. A new species of Anthaxia (Agrilaxia) Karremans from Natal (Coleoptera, Buprestidae). J Entomol Soc South Afr. 49(2):193-196.

Bernhardt P. 1989. The floral ecology of Australian Acacia. In: Stirton CH, Zarucchi $\mathrm{JL}$, editors. Advances in legume biology. Monographs in systematic botany from the Missouri botanical gardens 29. St. Louis: Missouri Botanical Garden; p. 263-282.

Bernhardt P. 2000. Convergent evolution and adaptive radiation of beetlepollinated angiosperms. PI Syst Evol. 222:293-320. https://doi.org/10.1007/ BF00984108

Bernhardt P, Thien LB. 1987. Self-isolation and insect pollination in the primitive angiosperms: new evaluations of older hypotheses. PI Syst Evol. 156:159-176. https://doi.org/10.1007/BF00936071

Biella P, Akter A, Ollerton J, Tarrant S, Janeček Š, Jersakova J, Klečka J. 2019. Experimental loss of generalist plants reveals alterations in plant-pollinator interactions and a constrained flexibility of foraging. Sci Rep. 9:7376. https:// doi.org/10.1038/s41598-019-43553-4

Bouchard P, Bousquet Y, Davies AE, Alonso-Zarazaga MA, Lawrence JF, Lyal CHC, Newton AF, Reid CAM, Schmitt M, Ślipiński SA, et al. 2011. Family-group names in Coleoptera (Insecta). Zookeys. 88:1-972.

Britton EB. 1970. Coleoptera. In: Britton EB, Brown WL, Calaby JH, editors. Insects of Australia. 1st ed. Melbourne: Melbourne University Press; p. 495-622.

Brosi BJ. 2016. Pollinator specialization: from the individual to the community. New Phytol. 210:1190-1194. https://doi.org/10.1111/nph.13951

Buchmann S, Nabhan G. 1996. The forgotten pollinators. Washington (DC): Island Press; p. 312. 
Burgess KH. 1991. Florivory: the ecology of flower feeding insects and their host plants [PhD Thesis]. Cambridge (MA): Harvard University; p. 224.

Burke HR. 1976. Bionomics of the anthonomine weevils. Annu Rev Entomol. 21:283-303. https://doi.org/10.1146/annurev.en.21.010176.001435

Cai C, Escalona HE, Li L, Yin Z, Huang D, Engel MS. 2018. Beetle pollination of cycads in the Mesozoic. Curr Biol. 28:1-7. https://doi.org/10.1016/j. cub.2018.06.036

Cardinal S, Danforth BN. 2013. Bees diversified in the age of eudicots. Proc R Soc B. 280:20122686. https://doi.org/10.1098/rspb.2012.2686

Colwell RK. 2013. EstimateS: statistical estimation of species richness and shared species from samples. Version 9. User's Guide and application published at. [accessed 2020 Aug 19]. http://purl.oclc.org/estimates

Cook SM, Murray DA, Williams IH. 2004. Do pollen beetles need pollen? The effect of pollen on oviposition, survival, and development of a flower-feeding herbivore. Ecol Entomol. 29:164-173. https://doi. org/10.1111/j.0307-6946.2004.00589.x

Corlett TR. 2004. Flower visitors and pollination in the Oriental (Indomalayan) region. Biol Rev. 79:497-532. https://doi.org/10.1017/S1464793103006341

Crowson RA. 1981. The biology of Coleoptera. London: Academic Press; p. 802.

Dafni A, Bernhardt P, Shmida A, Ivri Y, Greenbau S, O'Toole C, Losito L. 1990. Red bowl-shaped flowers: convergence for beetle pollination in the Mediterranean region. Isr J Bot. 39:81-92.

Daly DC, Mitchell JD. 2000. Lowland vegetation of tropical South America - an overview. In: Lentz D, editor. Imperfect balance: landscape transformations in the pre-Columbian Americas. New York: Columbia University Press; p. 391-454.

Dayanandan S, Attygalla DNC, Abeygunasekera AWWL, Gunatilleke IAUN, Gunatilleke CVS. 1990. Phenology and floral morphology in relation to pollination of some Sri Lankan dipterocarps. In: Bawa KS, Hadley M, editors. Reproductive ecology of tropical forest plants. Paris: Parthenon Publishing Group; p. 103-134.

Dinerstein E, Olson DM, Graham DJ, Webster AL, Primm SA, Bookbinder MP, Ledec G, World Wildlife Fund. 1995. A conservation assessment of the terrestrial ecoregions of Latin America and the Caribbean. Washington (DC): World Bank. http://documents.worldbank.org/curated/en/957541468270313045/Aconservation-assessment-of-the-terrestrialecoregions-

Dobson HEM. 2006. Relationship between floral fragrance composition and type of pollinator. In: Dudareva N, Pichersky E, editors. Biology of floral scent. Boca Raton: Taylor \& Francis; p. 147-198.

Englund R. 1993. Movement patterns of Cetonia beetles (Scarabaeidae) among flowering Viburnum opulus (Caprifoliaceae). Option for long-distance pollen dispersal in a temperate shrub. Oecologia. 94:295-302. https://doi. org/10.1007/BF00341330 
Engwald S, Schmit-Neuerburg V, Barthlott W. 2000. Epiphytes in rain forests of Venezuela - diversity and dynamics of a biocenosis. In: Breckle SW, Schweizer $B$, Arndt $U$, editors. Results of worldwide ecological studies. Proceedings of the 1st symposium by the A.F.W Schimper- foundation - from H. and E. Walter Hoheneim, Oktober 1998. Stuttgart-Hohenheim: Verlag Gunter Heimbach; p. 425-434.

Erwin TL. 1983. Tropical forest canopies: the last biotic frontier. Bull Entomol Soc Am. 29:14-19.

Erwin TL. 1995. Measuring arthropod biodiversity in the tropical forest canopy. In: Lowman MD, Nadkarni NM, editors. Forest Canopies. San Diego: Academic Press; p. 109-127.

Faegri K, Van der Pijl L. 1979. The principles of pollination ecology. Oxford (NY): Pergamon Press; p. 244.

Fenster CB, Armbruster WS, Wilson P, Dudash MR, Thomson JD. 2004. Pollination syndromes and floral specialization. Ann Rev Ecol Evol Syst. 35:375-403. https://doi.org/10.1146/annurev.ecolsys.34.011802.132347

Fishbein M, Venable DL. 1996. Diversity and temporal change in the effective pollinators of Asclepias tuberosa. Ecology. 77:1061-1073. https://doi. org/10.2307/2265576

Frame D. 2003. Generalist flowers, biodiversity and florivory: implications for angiosperm origins. Taxon. 52:681-685. https://doi.org/10.2307/4135541

Frankie EG. 1975. Tropical forest phenology and pollinator plant coevolution. In: Gilbert LE, Raven PH, editors. Coevolution of animals and plants. Austin \& London: University of Texas Press; p. 192-209.

Frankie GW, Baker HG, Opler PA. 1974. Comparative phonological studies of trees in tropical wet and dry forests in the lowlands of Costa Rica. J Ecol. 62:881-919. https://doi.org/10.2307/2258961

Fuchs GV. 1974. Die Gewinnung von Pollen und Nektar bei Kafern [The utilization of pollen and nectar in beetles]. Nat Mus. 104:45-54. German.

Galetto L, Bernardello G. 2003. Nectar sugar composition in angisoperms from Chaco and Patagonia (Argentina): an animal visitor's matter? PI Syst Evol. 238:69-86. https://doi.org/10.1007/s00606-002-0269-y

Gandolfo MA, Nixon KC, Crepet WL. 2004. Cretaceous flowers of Nymphaeaceae and implications for complex insect entrapment pollination mechanisms in early angiosperms. Proc Natl Acad Sci USA. 101:8056-8060. https://doi. org/10.1073/pnas.0402473101

Gang H, Zhongjian L, Xueling L, Limi M, Jacques FMB, Xin W. 2016. A whole plant herbaceous angiosperm from the Middle Jurassic of China. Acta Geol Sin. 90:19-29. https://doi.org/10.1111/1755-6724.12592

Garcia-Robledo C, Kattan G, Murcia C, Quintero P. 2004. Beetle pollination and fruit predation in Xanthosoma daguense (Araceae). J Trop Ecol. 20:459-469. https://doi.org/10.1017/S0266467404001610

Gardner JA. 1989. Revision of the genera of the tribe Stignodermini (Coleoptera: buprestidae) with a discussion of phylogenetic relationships. Invertebr Taxon. 3:291-361. https://doi.org/10.1071/IT9890291 
Gasca AHJ, Higuera DD. 2010. Protocols and methods to study of canopy arthropods in Neotropical cloud forest. Rev Colombiana Cienc Anim. 2(2):385-398.

Gaston KJ, Williams PH, Eggleton P, Humphries CJ. 1995. Large scale patterns of biodiversity: spatial variation in family richness. Proc R Soc Ser B. 260:149-154.

Gentry AH. 1982. Neotropical floristic diversity: phytogeographical connections between Central and South America, Pleistocene climatic fluctuations, or an accident of the Andean Orogeny? Ann Missouri Bot Gard. 69(3):557-593. https://doi.org/10.2307/2399084

Goldblatt P, Manning JC. 2006. Radiation of pollination systems in the Iridaceae of sub-Saharan Africa. Ann Bot. 97(3):317-344. https://doi.org/10.1093/aob/ mcj040

Goldburg RJ. 1987. Sequential flowering of neighboring goldenrods and the movements of Epicauta pennsylvanica. a pollen-feeding meloid beetle. Oecologia. 74:247-252. https://doi.org/10.1007/BF00379366.

Goldstein J, Zych M. 2016. What if we lose a hub? Experimental testing of pollination network resilience to removal of keystone floral resources. Arthropod-Plant Interact. 10:263-271. https://doi.org/10.1007/ s11829-016-9431-2

Gomez JM, Zamora R. 2006. Ecological factors that promote the evolution of generalization in pollination systems. In: Waser NM, Ollerton J, editors. Plant-pollinator interactions, from specialization to generalization. Chicago: University of Chicago Press; p. 145-165.

Gomez JM, Bosch J, Perfectti F, Fernandez J, Abdelaziz M. 2007. Pollinator diversity affects plant reproduction and recruitment: the tradeoffs of generalization. Oecologia. 153:597-605. https://doi.org/10.1007/s00442-007-0758-3

Gottsberger G. 1974. The structure and function of the primitive Angiosperm flower. Acta Bot Neerl. 23:461-471. https://doi.org/10.1111/j.1438-8677.1974. tb00962.x

Gottsberger G. 1988. The reproductive biology of primitive angiosperms. Taxon. 37:630-643. https://doi.org/10.2307/1221105

Gottsberger G. 1989. Beetle pollination and flowering rhythm of Annona spp. (Annonaceae) in Brazil. Plant Syst Evol. 167:165-187. https://doi.org/10.1007/ BF00936404 Gottsberger G. 1990. Flowers and beetles in the South American tropics. Bot Acta. 103:360-365. https://doi.org/10.1111/j.1438-8677.1990. tb00175.x

Gottsberger G. 1999. Pollination and evolution in neotropical Annonaceae. Plant Species Biol. 14:143-152. https://doi.org/10.1046/j.1442-1984.1999.00018.x

Gottsberger G. 2012. How diverse are Annonaceae with regard to pollination? Bot J Linn Soc. 169:170-183. https://doi.org/10.1111/j.1095-8339.2011.01209.x

Gottsberger G. 2016. Generalist and specialist pollination in basal angiosperms (ANITA grade, basal monocots, magnoliids, Chloranthaceae and Ceratophyllaceae): what we know now. Plant Divers Evol. 131:263-362. https:// doi.org/10.1127/pde/2015/0131-0085 
Gottsberger G, Silberbauer-Gottsberger I. 1991. Olfactory and visual attraction of Erioscelis emarginata (Cyclocephalini, Dynastinae) to the inflorescences of Philodendron selloum (Araceae). Biotropica. 23(1):23-28. https://doi. org/ $10.2307 / 2388684$

Gottsberger G, Silberbauer-Gottsberger I. 2018. How are pollination and seed dispersal modes in Cerrado related to stratification? Trends in a cerrado sensu stricto woodland in southeastern Brazil, and a comparison with Neotropical forests. Acta Bot Bras. 1-12. https://doi.org/10.1590/0102-33062018abb0186

Goulson D. 1999. Foraging strategies of insects for gathering nectar and pollen, and implications for plant ecology and evolution. Persp Plant Ecol Evol System. 2/2:185-209. https://doi.org/10.1078/1433-8319-00070

Grimaldi D. 1999. The co-radiations of pollinating insects and angiosperms in the Cretaceous. Ann Missouri Bot Gard. 86:373-406. https://doi. org/10.2307/2666181

Grinfeld EK. 1975. Anthophily in beetles (Coleoptera) and criticism of the cantharophilous hypothesis. Entomol Obozr. 54:18-22.

Hamilton AJ, Basset Y, Benke KK, Grimbacher PS, Miller SE, Novotny V, Samuelson GA, Stork NE, Weiblen GD, Yen GDL. 2010. Quantifying uncertainty in estimation of tropical arthropod species richness. Am Nat. 176:90-95. https:// doi.org/10.1086/652998

Hammer O, Harper DAT, Ryan PD. 2001. PAST: palaeontological statistics software package for education and data analysis. Palaeontol Electronica. 4(1):9.

Hansman DJ. 2001. Floral biology of dry rainforest in north Queensland and a comparison with adjacent savanna woodland. Aust J Bot. 49:137-153. https:// doi.org/10.1071/BT00017

Hawkeswood TJ. 1978. Observations on some Buprestidae (Coleoptera) from the Blue Mountains. N S W Aust Zool. 19:257-275.

Heinrich B, Raven P. 1972. Energetics and pollination ecology. Science. 176:597602. https://doi.org/10.1126/science.176.4035.597

Herrera CM. 1988. Variation in mutualisms: the spatiotemporal mosaic of a pollinator assemblage. Biol J Linn Soc. 35:95-125. https://doi. org/10.1111/j.1095-8312.1988.tb00461.x

Howe HF, Westley LC. 1986. Ecology of pollination and seed dispersal. In: Crawley M, editor. Plant ecology. Oxford (UK): Blackwells; p. 185-215.

Hu S, Dilcher DL, Jarzen DM, Winship Taylor D. 2008. Early steps of angiospermpollinator coevolution. Proc Natl Acad Sci USA. 105:240-245. https:// doi.org/10.1073/pnas.0707989105 Irvine AK, Armstrong JE. 1990. Beetle pollination in tropical forests of Australia. In: Bawa KS,

Hadley M, editors. Reproductive ecology of tropical forest plants. Man and the biosphere series 7. Carnforth: UNESCO,Paris and Parthenon Publ; p. 135-149.

Jackman JA, Lu WH. 2002. 101. MORDELLIDAE Latreille 1802. In: Arnett RH, Thomas MC, Skelley PE, Frank JH, editors. American beetles. Boca Raton (FL): CRC Press; p. 423-430. 
Jervis MA. 1998. Functional and evolutionary aspects of mouthpart structure in parasitoid wasps. Biol J Linn Soc. 63:461-493. https://doi. org/10.1111/j.1095-8312.1998.tb00326.x

Johnson SA, Nicolson SW. 2001. Pollen digestion by flower-feeding Scarabaeidae: Protea beetles (Cetoniini) and monkey beetles (Hopliini). J Insect Physiol. 47:725-733. https://doi.org/10.1016/S0022-1910(00)00166-9

Jolivet P, Hawkeswood TJ. 1995. Host-plants of the Chrysomelidae of the World. Leiden: Backhuys Publishers; p. 281.

Kato M. 1996. Plant-pollinator interactions in the understory of a lowland mixed dipterocarp forest in Sarawak. Am J Bot. 86:732-743. https://doi. org/10.1002/j.1537-2197.1996.tb12762.x

Kato M, Kakutani T, Inoue T, Itino T. 1990. Insect flower relationship in the primary beech forest of Ashu, Kyoto: an overview of the flowering phenology and the seasonal pattern of insect visits. Contr Biol Lab Kyoto Univ. 27:309-375.

Kato M, Kosaka Y, Kawakita A, Okuyama Y, Kobayashi C, Phimminith T, Thongphan D. 2008. Plant - pollinator interactions in tropical Monsoon forests in Southeast Asia. Am J Bot. 95(11):1375-1394. https://doi.org/10.3732/ajb.0800114

Kearns CA, Inouye DW. 1997. Pollinators, flowering plants, and conservation biology. BioScience. 47:297-307. https://doi.org/10.2307/1313191

Keeler KH. 1977. The extrafloral nectaries of Ipomoea carnea (Convolvulaceae). Am J Bot. 64 (10):1282-1288. https://doi.org/10.1002/j.1537-2197.1977. tb10810.x

Kevan P, Baker HB. 1983. Insects as flower visitors and pollinators. Annu Rev Entomol. 28:407-454. https://doi.org/10.1146/annurev.en.28.010183.002203

Kirmse S, Adis J, Morawetz W. 2003. Flowering events and beetle diversity in Venezuela. In: Basset Y, Novotny V, Miller SE, Kitching RL, editors. Arthropods of tropical forests. Spatiotemporal dynamics and resource use in the canopy. Cambridge: Cambridge University Press; p. 256-265.

Kirmse S, Chaboo CS. 2018. Polyphagy and florivory prevail in a leaf-beetle community (Coleoptera: chrysomelidae) inhabiting the canopy of a tropical lowland rainforest in southern Venezuela. J Nat Hist. 52(41-42):2677-2721. https://doi.org/10.1080/00222933.2018.1548666

Kirmse S, Chaboo CS. 2019. Extrafloral nectaries mediate the arboreal beetle community (Coleoptera) in a Neotropical rainforest. J Nat Hist. 53(2122):1313-1349. https://doi.org/10.1080/00222933.2019.1650211

Kirmse S, Johnson PJ. 2020. Host-use patterns of canopy-inhabiting click beetles (Coleoptera: elateridae) in a lowland rainforest in southern Venezuela. Insecta Mundi. 0794:1-16.

Kirmse S, Ratcliffe BC. 2019. Composition and host-use patterns of a scarab community (Coleoptera: scarabaeidae) inhabiting the canopy of a lowland tropical rainforest in southern Venezuela. Coleop Bull. 73(1):149-167. https:// doi.org/10.1649/0010-065X-73.1.149 
Knudsen JT, Tollsten L. 1993. Trends in floral scent chemistry in pollination syndromes. Floral scent composition in mothpollinated taxa. Bot J Linn Soc. 113:263-284. https://doi.org/10.1111/j.1095-8339.1993.tb00340.x

Komposch H, Hafellner J. 2000. Diversity and vertical distribution of lichens in a Venezuelan tropical lowland rain forest. Selbyana. 21:11-24.

Koptur S, Khorsand R. 2018. Pollination ecology of three sympatric palms of Southern Florida Pine Rocklands. Nat Areas J. 38(1):15-25. https://doi. org/10.3375/043.038.0104

Krenn HW, Plant JD, Szucsich NU. 2005. Mouthparts of flower visiting insects. Arthropod Struct Dev. 34:1-40. https://doi.org/10.1016/j.asd.2004.10.002

Kress WJ, Beach JH. 1994. Flowering plant reproductive systems. In: McDade LA, Bawa KS, Hespenheide HA, Hartshorn GS, editors. La Selva - Ecology and natural history of a Neotropical rain forest. Chicago/London: University of Chicago Press; p. 161-182.

Kuchmeister H, Silberbauer-Gottsberger I, Gottsberger G. 1997. Flowering, pollination, nectar standing crop, and nectaries of Euterpe precatoria (Arecaceae), an Amazonian rain forest palm. Plant Syst Evol. 206:71-97. https:// doi.org/10.1007/BF00987942

Labandeira CC. 1998. How old is the flower and the fly? Science. 280:57-59. https://doi.org/10.1126/science.280.5360.57

Lamborn E, Ollerton J. 2000. Experimental assessment of the functional morphology of inflorescences of Daucus carota (Apiaceae): testing the "fly catcher effect". Funct Ecol. 14:445-454. https://doi. org/10.1046/j.1365-2435.2000.00440.x

Listabarth C. 1992. A survey of pollination strategies in the Bactridinae. Bull Inst Fr Etudes Andines. 21:699-714.

Listabarth C. 1994. Pollination and pollinator breeding in Desmoncus. Principes. 3(1):13-23.

Listabarth C. 1999. The palms of the Surumoni area (Amazonas, Venezuela). I. Assemblage com position and survey of pollination strategies. Acta Bot Venez. 22:141-151.

Lobo JA, Quesada M, Stoner KE, Fuchs EJ, Herrerias-Diego Y, Rojas J, Saborio G. 2003. Factors affecting phenological patterns of bombacaceous trees in seasonal forests in Costa Rica and Mexico. Am J Bot. 90:1054-1063. https://doi. org/10.3732/ajb.90.7.1054

Martin Gonzalez AM, Dalsgaard B, Olesen JM. 2010. Centrality measures and the importance of generalist species in pollination networks. Ecol Complex. 7:3643. https://doi.org/10.1016/j.ecocom.2009.03.008

McCall AC, Irwin RE. 2006. Florivory: the intersection of pollination and herbivory. Ecol Lett. 9 (12):1351-1365. https://doi.org/10.1111/j.1461-0248.2006.00975.x

McKenna DD, Shina S, Ahrens D, Balke M, Beza-Beza C, Clarke DJ, Donath A, Escalona HE, Friedrich $F$, Letsch $\mathrm{H}$, et al. 2019. The evolution and genomic basis of beetle diversity. Proc Natl Acad Sci. 116 (49):24729-24737. https://doi. org/10.1073/pnas.1909655116 
McKeown KC. 1947. Catalogue of the Cerambycidae (Coleoptera) of Australia. Mem Aust Mus. 10:1-190. https://doi.org/10.3853/j.0067-1967.10.1947.477

Miller SE, Novotny V, Basset Y. 2002. Case studies of arthropod diversity and distribution. In: Chazdon RL, Whitmore TC, editors. Foundations of tropical forest biology: classic papers with commentaries. Chicago: University of Chicago Press; p. 407-413.

Momose K, Inoue T. 1994. Pollination syndromes in the plant-pollinator community in the lowland mixed dipterocarp forests of Sarawak. In: Inoue T, Hamid A, editors. Plant reproductive systems and animal seasonal dynamics. Canopy biology program in Sarawak (CBPS): series 1. Japan: Center for Ecological Research, Kyoto University; p. 119-141.

Momose K, Yumoto T, Nagamitsu T, Kato M, Nagamitsu M, Sakai S, Harrison RD, Itioka T, Hamid AA, Inoue T. 1998. Pollination biology in a lowland dipterocarp forest in Sarawak, Malaysia. I. Characteristics of the plant - pollinator community in a lowland dipterocarp forest. Am J Bot. 85:1477-1501. https:// doi.org/10.2307/2446404

Montoya D, Rogers L, Memmott J. 2012. Emerging perspectives in the restoration of biodiversity-based ecosystem services. Trends Ecol Evol. 27:666-672. https:// doi.org/10.1016/j.tree.2012.07.004

Morawetz W. 1998. The Surumoni project: the botanical approach toward gaining an interdisciplinary understanding of the functions of the rain forest canopy. In: Barthlott W, Winiger MN, editors. Biodiversity: a challenge for development research and policy. Berlin: Springer-Verlag; p. 71-80.

Morawetz W, Liebig A, Wesenberg J. 1998. Ein Vegetationsprofil im Untersuchungsgelande des Surumoni-Projektes bei La Esmeralda/Oberer Orinoko [A vegetation profile at the study plot of the Surumoni-project near La Esmeralda/upper Orinoco]. In: Dalitz H, Haverkamp M, Homeier J, Breckle S-W, editors. 11. Jahrestagung der Deutschen Gesellschaft fur Tropenokologie. Bielefeld (German): GTO. Biel. Okol. Beitr. p. 128.

Morrone JJ. 2014. Monograph biogeographical regionalisation of the Neotropical region. Zootaxa. 3782(1):1-110. https://doi.org/10.11646/zootaxa.3782.1.1

Myers N, Mittermeier RA, Mittermeier CG, da Fonseca GA, Kent J. 2000. Biodiversity hotspots for conservation priorities. Nature. 403:853-858. https:// doi.org/10.1038/35002501

Newstrom LE, Frankie GW, Baker HG, Colwell RK. 1994. Diversity of long-term flowering patterns. In: McDade LA, Bawa KS, Hespenheide HA, Hartshorn GS, editors. La Selva: ecology and natural history of a neotropical rain forest. Chicago: University of Chicago Press; p. 142-160.

Nicolson SW. 2007. Chapter 7. Nectar consumers. In: Nicolson SW, Nepi M, Pacini E, editors. Nectaries and Nectar. Dordrecht: Springer; p. 289-342.

Nicolson SW, Thornburg RW. 2007. Nectar chemistry. In: Nicolson SW, Nepi M, Pacini E, editors. Nectaries and nectar. Dordrecht: Springer; p. 215-264. 
Nieder J, Engwald S, Klawun M, Barthlott W. 2000. Spatial distribution of vascular epiphytes (including Hemiepiphytes) in a lowland Amazonian rain forest (Surumoni crane plot) of southern Venezuela. Biotropica. 32(3):385-396. https://doi.org/10.1111/j.1744-7429.2000.tb00485.x

Odegaard F, Frame D. 2007. Generalist flowers and phytophagous beetles in two tropical canopy trees: resources for multitudes. Taxon. 56(3):696-706. https:// doi.org/10.2307/25065853

Olesen JM. 1992. Flower mining by moth larvae vs. pollination by beetles and bees in the cauliflorous Sapranthus palanga (Annonaceae) in Costa Rica. Flora. 187:9-15. https://doi.org/10.1016/S0367-2530(17)32201-6

Olesen JM. 2000. Exactly how generalised are pollination interactions? In: Totland O, Armbruster WS, Fenster C, Molua U, Nilsson LA, Olesen JM, Ollerton J, Philipp M, Agren J, editors. The Scandinavian association for pollination ecology Honours Knut Fagri. Oslo: The Norwegian Academy of Science and Letters; p. 161-178.

Olesen JM, Dupont YL, Ehlers BK, Hansen DM. 2007. The openness of a flower and its number of flower-visitor species. Taxon. 56(3):729-736. https://doi. org/10.2307/25065856

Oliveira Lourenco SM, Luiz MF, Goncalves de Jesus F, Costa Carvalho DD, Hornburg M, da Silva Araujo M. 2017. Predispersal infestation of Vochysia haenkeana seeds by Lius conicus. Ciencia Rural, Santa Maria. 47(9):e20160953.

Ollerton J, Johnson SD, Hingston AB. 2006. Geographical variation in diversity and specificity of pollination systems. In: Waser NM, Ollerton J, editors. Plant-pollinator interactions: from specialization to generalization. Chicago: University of Chicago Press; p. 283-308.

Ollerton J. 2012. Biogeography: are tropical species less specialized? Curr Biol. 22:R914-R915. https://doi.org/10.1016/j.cub.2012.09.023

Ollerton J. 2017. Pollinator diversity: distribution, ecological function, and conservation. Annu Rev Ecol Evol Syst. 48:353-376. https://doi.org/10.1146/ annurev-ecolsys-110316-022919

Ollerton J, Cranmer L. 2002. Latitudinal trends in plant-pollinator interactions: are tropical plants more specialized? Oikos. 98(2):340-345. https://doi. org/10.1034/j.1600-0706.2002.980215.x

Ollerton J, Johnson SD, Cranmer L, Kellie S. 2003. The pollination ecology of an assemblage of grassland Asclepiads in South Africa. Ann Bot. 92:807-834. https://doi.org/10.1093/aob/mcg206

Ollerton J, Killick A, Lamborn E, Watts S, Whiston M. 2007. Multiple meanings and modes: on the many ways to be a generalist flower. Taxon. 56(3):1-12. https:// doi.org/ $10.2307 / 25065856$

Ollerton J, Winfree R, Tarrant S. 2011. How many flowering plants are pollinated by animals? Oikos. 120:321-326. https://doi. org/10.1111/j.1600-0706.2010.18644.x

Olsen KM. 1997. Pollination effectiveness and pollinator importance in a population of Heterotheca subaxillaris (Asteraceae). Oecologia. 10:114-121. 
Paton AJ, Brummitt N, Govaerts R, Harman K, Hinchcliffe S, Allkin B, Lughadha EN. 2008. Towards target 1 of the global strategy for plant conservation: a working list of all known plant species- progress and prospects. Taxon. 57:602-611.

Petanidou T, Potts SG. 2006. Mutual use of resources in Mediterranean plantpollinator communities: how specialized are pollination webs? In: Waser $\mathrm{NM}$, Ollerton J, editors. Plant-pollinator interactions: from specialization to generalization. Chicago: University of Chicago Press; p. 220-244.

Petanidou T, Kallimanis AS, Tzanopoulos J, Sgardelis SP, Pantis JD. 2008. Long term observation of a pollination network: fluctuation in species and interactions, relative invariance of network structure and implications for estimates of specialization. Ecol Lett. 11:564-575. https://doi. org/10.1111/j.1461-0248.2008.01170.x

Pettersson MW. 1991. Pollination by a guild of fluctuating moth populations: option for unspecialization in Silene vulgaris. J Ecol. 79:591-604. https://doi. org/10.2307/2260655

Pianka ER. 1966. Latitudinal gradients in species diversity: a review of concepts. Am Nat. 100:3346. https://doi.org/10.1086/282398

Pornon A, Baksay S, Escaravage N, Burrus M, Andalo C. 2019. Pollinator specialization increases with a decrease in a mass-flowering plant in networks inferred from DNA metabarcoding. Ecol Evol. 9:13650-13662.

Prance GT. 1979. Notes on the vegetation of Amazonia III. The terminology of Amazonian forest types subject to inundation. Brittonia. 31(1):26-38. https:// doi.org/10.2307/2806669

Prance GT, Sothers C. 2009. Neotropical Chrysobalanaceae. In: Milliken W, Klitgard B, Baracat A, editors. Neotropikey - Interactive key and information resources for flowering plants of the Neotropics. [accessed 2020 Aug 19]. http://www. kew.org/science/tropamerica/neotropikey/families/Chrysobalanaceae.htm

Proches Ş, Johnson SD. 2009. Beetle pollination of the fruit-scented cones of the South African Cycad Stangeria eriopus. Am J Bot. 96(9):1722-1730. https://doi. org/10.3732/ajb.0800377

Proctor M, Yeo P, Lack A. 1996. The natural history of pollination. Portland (OR): Timber Press; p. 479.

Ramirez N, Seres A. 1994. Plant reproductive biology of herbaceous monocots in a Venezuelan tropical cloud forest. Plant Syst Evol. 190:129-142. https://doi. org/10.1007/BF00986189

Reverte S, Retana J, Gomez JM, Bosch J. 2016. Pollinators show flower colour preferences but flowers with similar colours do not attract similar pollinators. Ann Bot. 118:249-257. https://doi.org/10.1093/aob/mcw103

Richardson DM, Allsopp N, D'Antonio CM, Milton SJ, Rejmanek M. 2000. Plant invasions-the role of mutualisms. Biol Rev. 75:63-99. https://doi.org/10.1017/ $\underline{\text { S0006323199005435 }}$

Rosas-Guerrero V, Aguilar R, Marten-Rodriguez S, Ashworth L, LopezaraizaMikel M, Bastida JM, Quesada M. 2014. A quantitative review of pollination syndromes: do floral traits predict effective pollinators? Ecol Lett. 17:388-400. https://doi.org/10.1111/ele.12224 
Sahli HF, Conner JK. 2006. Characterizing ecological generalization in plantpollination systems. Oecologia. 148:365-372. https://doi.org/10.1007/ s00442-006-0396-1

Sakai S. 2001. Phenological diversity in tropical forests. Popul Ecol. 43:77-86. https://doi.org/10.1007/PL00012018

Sakai S, Momose K, Yumoto T, Kato M, Inoue T. 1999. Beetle pollination of Shorea parvifolia (section Mutica, Dipterocarpaceae) in a general flowering period in Sarawak, Malaysia. Am J Bot. 86:62-69. https://doi.org/10.2307/2656955

Samuelson GA. 1989. Pollen feeding in Alticinae (Chrysomelidae). Entomographica. 6:407-411.

Sayers TDJ, Steinbauer MJ, Miller RE. 2019. Visitor or vector? The extent of rove beetle (Coleoptera: Staphylinidae) pollination and floral interactions. Arthropod Plant Interact. 13:685. https://doi.org/10.1007/s11829-019-09698-9

Scambler DJ. 1993. Ischnauchen, a new genus for Aphiohrynchus costatus McKeown (Coleoptera: cerambycidae). J Aust Entomol Soc. 32:193-195. https:// doi.org/10.1111/j.1440-6055.1993.tb00570.x

Schleuning M, Frund J, Klein AM, Abrahamczyk S, Alarcon R, Albrecht M, Andersson GKS, Bazarian S, Bohning-Gaese K, Bommarco R, et al. 2012. Specialization of mutualistic interaction networks decreases toward tropical latitudes. Curr Biol. 22:1925-1931. https://doi.org/10.1016/j.cub.2012.08.015

Ślipiński SA, Leschen RAB, Lawrence JF. 2011. Order Coleoptera Linneaus, 1758. In: zhang Z-Q, editor. Animal biodiversity: an outline of higher-level classification and survey of taxonomic richness. Zootaxa. 3148:203-208. https://doi. org/10.11646/zootaxa.3148.1.39

Simpson BB, Neff JL. 1983. Evolution and diversity of floral rewards. In: Jones CE, Little RL, editors. Handbook of pollination biology. New York: Van Nostrand Reinhold; p. 360-372.

Smith-Ramirez C, Martinez P, Nunez M, Gonzalez C, Armesto JJ. 2005. Diversity, flower visitation frequency and generalism of pollinators in temperate rain forests of Chiloe Island, Chile. Bot J Linn Soc. 147:399-416. https://doi. org/10.1111/j.1095-8339.2005.00388.x

Sothers CA, Prance GT, Chase MW. 2016. Towards a monophyletic Licania: a new generic classification of the polyphyletic Neotropical genus Licania. Kew Bull. 71:58. https://doi.org/10.1007/s12225-016-9664-3

Stebbins GL. 1970. Adaptive radiation of reproductive characteristics in angiosperms. I: pollination mechanisms. Ann Rev Ecol Syst. 1:307-326. https:// doi.org/10.1146/annurev.es.01.110170.001515

Stork NE. 1988. Insect diversity: facts, fiction and speculation. Biol J Linn Soc. 35:321-337. https://doi.org/10.1111/j.1095-8312.1988.tb00474.x

Stork NE. 2017. How many species of insects and other terrestrial Arthropods are there on earth? Annu Rev Entomol. 63:31-45. https://doi.org/10.1146/ annurev-ento-020117-043348 
Ter Steege H, Vaessen RW, Cardenas-Lopez D, Sabatier D, Antonelli A, Mota de Oliveira S, Pitman NCA, Moller Jorgensen P, Salomao RP. 2016. The discovery of the Amazonian tree flora with an updated checklist of all known tree taxa. Sci Rep. 6(29549):1-15. https://doi.org/10.1038/srep29549

Thien LB, Bernhardt P, Devall MS, Chen ZD, Luo YB, Fan JH, Yuan L-C, Williams JH. 2009. Pollination biology of basal angiosperms (ANITA grade). Am J Bot. 96:166-182. https://doi.org/10.3732/ajb.0800016

Valverde J, Perfectti F, Gomez JM. 2019. Pollination effectiveness in a generalist plant: adding the genetic component. New Phytologist. 223(1):354-365. https://doi.org/10.1111/nph.15743

Vazquez DP, Aizen MA. 2004. Asymmetric specialization: a pervasive feature of plant-pollinator interactions. Ecology. 85:1251-1257. https://doi. org/10.1890/03-3112

Vazquez DP, Morris WF, Jordano P. 2005. Interaction frequency as a surrogate for the total effect of animal mutualists on plants. Ecol Lett. 8:1088-1094. https:// doi.org/10.1111/j.1461-0248.2005.00810.x

Vazquez DP, Ramos-Jiliberto R, Urbani P, Valdovinos FS. 2015. A conceptual framework for studying the strength of plant-animal mutualistic interactions. Ecol Lett. 18:385-400. https://doi.org/10.1111/ele.12411

Vinicius LGB, Rech AR, Ollerton J, Sazima M. 2017. Nectar production, reproductive success and the evolution of generalised pollination within a specialized pollen-rewarding plant family: a case study using Miconia theizans. PI Syst Evol. https://doi.org/10.1007/s00606-017-1405-z

Vizentin-Bugoni J, Maruyama PK, Souza CS, Ollerton J, Rech AR, Sazima M. 2018. Plant-pollinator networks in the tropics: a review. In: Dattilo W, Rico-Gray V, editors. Ecological networks in the tropics. Cham: Springer; p. 73-91.

Wackers FL, Romeis J, van Rijn P. 2007. Nectar and pollen feeding by insect herbivores and implications for multitrophic interactions. Annu Rev Entomol. 52:301-323. https://doi.org/10.1146/annurev.ento.52.110405.091352

Wardhaugh CW. 2015. How many species of arthropods visit flowers? Arthropod Plant Interact. 9 (6):547-565. https://doi.org/10.1007/s11829-015-9398-4

Wardhaugh CW, Stork NE, Edwards W. 2013. Specialisation of rainforest canopy beetles to host trees and microhabitats: not all specialists are leaf-feeding herbivores. Biol J Linn Soc. 109:215-228. https://doi.org/10.1111/bij.12029

Wardhaugh CW, Stork NE, Edwards W, Grimbacher PS. 2012. The overlooked biodiversity of flower-visiting invertebrates. PLoS One. 7:e45796.

PMID:23029246. https://doi.org/10.1371/journal.pone.0045796

Waser NM, Chittka L, Price MV, Williams NM, Ollerton J. 1996. Generalization in pollination systems, and why it matters. Ecology. 77:1043-1060. https://doi. org/10.2307/2265575

Watts S, Dormann CF, Gonzalez AAM, Ollerton J. 2016. The influence of floral traits on specialisation and modularity of plant-pollinator networks in a biodiversity hotspot in the Peruvian Andes. J Ann Bot. 118(3):415-429. https:// doi.org/10.1093/aob/mcw114 
Wesenberg J. 2004. Bluhphanologie im Kronenraum eines tropischen Tieflandregenwaldes am Oberen Orinoco, Amazonas, Venezuela [Flower phenology in the canopy of a tropical lowland rainforest at the upper Orinoco, Amazonas, Venezuela] [dissertation]. German: Fakultat fur Biowissenschaften, Pharmazie und Psychologie, Universitat Leipzig.

Willmer P, editor. 2011. Pollination and floral ecology. Princeton (NJ): Princeton University Press; p. 778.

Willson MF, Bertin RI. 1979. Flower-visitors, nectar production, and inflorescence size of Asclepias syriaca. Can J Bot. 57:1380-1388. https://doi.org/10.1139/ b79-172

Winkler H, Listabarth C. 2003. Surumoni project, Venezuela. In: Basset Y, Horlyck $\mathrm{V}$, Wright SJ, editors. Studying forest canopies from above: the international Canopy crane network. Panama: Smithsonian Tropical Research Institute and UNEP; p. 126-136.

Wolda H, O'Brien CW, Stockwell HP. 1998. Weevil diversity and seasonality in tropical panama as deduced from light-trap catches (Coleoptera: Curculionoidea). Smithson Contrib Zool. 590:79.

Young HJ. 1990. Pollination and reproductive biology of an understory neotropical aroid. In: Bawa KS, Hadley M, editors. Reproductive ecology of tropical forest plants. Man and the biosphere series. Carnforth: Unesco, Paris and Parthenon Publishing; p. 151-164.

Zepeda-Gomez C, Velazquez-Montes E. 1999. El bosque tropical caducifolio de la vertiente sur de la sierra de Nanchititla, Estado de Mexico: la composicion y la afinidad geografica de su flora. Acta Bot Mex. 46:29-55. https://doi. org/10.21829/abm46.1999.815 